\title{
PENGGUNAAN SUKU BUNGA SEBAGAI \\ SASARAN OPERASIONAL KEBIJAKAN MONETER DI INDONESIA
}

\author{
Perry Warjiyo dan Doddy Zulverdi *)
}

Salah satu altematif pendekatan untuk meningkatkan kinerja kebijakan moneter Bank Indonesia adalah dengan menerapkan sistem pengendalian moneter menggunakan suku bunga sebagai sasaran operasional. Berkaitan dengan itu, hasil penelitian menunjukkan bahwa: i) terdapat suatu keyakinan yang cukup kuat bahwa transmisi kebijakan moneter melalui suku bunga menjadi semakin penting dibandingkan dengan transmisi melalui jumlah uang beredar sehingga penerapan sistem pengendalian moneter menggunakan suku bunga sebagai sasaran qperasional layak untuk dipertimbangkan; ii) terdapat hubungan yang cukup erat antara laju inflasi dan suku bunga (deposito berjangka satu bulan dan kredit modal kerja); dan iii) suku bunga PUAB dapat dipertimbangkan untuk menjadi sasaran gperasional karena meniliki kaitan yang erat dengan suku bunga deposito, menceminkan kondisi likuiditas di pasar uang, dan sekaligus dapat dipenganuhi oleh instnmen OPT khususnya suku bunga SBPU.

Terdapat beberapa syarat bagi efektivitas sistem pengendalian moneter menggunakan suku bunga sebagai sasaran querasional, yaitu: i) Sasaran akhir kebijakan moneter sebaiknya diprioritaskan pada pengendalian underlying/core inflation, yaitu komponen inflasi yang diyakini benar-benar dipenganuhi faktor-faktor moneter; ii) Untuk meminimalkan penganuh negatif tekanan-tekanan ekstemal terhadap efektivitas kebijakan moneter, sistem nilai tukar yang fleksibel (mengambang) menjadi pilihan utama dibandingkan dengan sistem nilai tukar tetap; iii) Anggaran pemerintah hanus "fully budget" dalam arti setiap defisit/sunplus anggaran hanus setiap saat dibiayai/diserap oleh instnmen utang pemerintah; iv) Untuk memelihara kestabilan pemintaan di pasar uang, kinerja sistem penbayaran harus terus-menerus ditingkatkan.

*) Perry Warjiyo : Deputi Kepala Urusan Riset Ekonomi dan Kebijakan Moneter, BI, Email: perry_w@bi.go.id

Doddy Zulverdi : Peneliti Ekonomi Yunior, Bag. Analisis dan Perencanaan Kebijakan, UREM, BI

Penulis mengucapkan terima kasih untuk diskusi dan komentar dari Triono Widodo, Kepala Bagian Studi Ekonomi Makro, UREM-BI, dan bantuan dalam proses penelitian kepada Siti Astiyah, Peneliti Ekonomi Yunior, Bagian Analisis dan Perencanaan Kebijakan, UREM-BI. 


\section{Pendahuluan}

fektivitas pengendalian moneter di Indonesia dalam beberapa tahun terakhir dirasakan semakin berkurang sebagaimana terlihat pada semakin sulitnya pencapaian sasaransasaran operasional berupa besaran-besaran moneter maupun sasaran-sasaran akhir khususnya laju inflasi dan neraca pembayaran. Permasalahan ini tampaknya terkait dengan perkembangan sistem, operasi, dan instrumen pasar keuangan yang pesat dan semakin kompleks serta peningkatan keterkaitan pasar keuangan domestik dan internasional yang telah berdampak pada:

- Berubahnya definisi, cakupan, dan perilaku uang beredar.

- Terjadinya proses pemisahan kegiatan antara sektor moneter dan sektor riil sehingga hubungan antara uang beredar dan berbagai variabel di sektor riil semakin sulit diprediksi.

- Semakin besar dan cepatnya arus lalu lintas modal sehingga uang beredar dalam jangka pendek menjadi berfluktuatif dan sulit dikendalikan.

Kondisi tersebut diyakini telah mengubah hubungan-hubungan kausalitas yang melandasi formulasi kebijakan moneter dan menuntut adanya peninjauan kembali atas relevansi paradigma monetaris yang selama ini melandasi kebijakan moneter Bank Indonesia. Berbagai negara dengan permasalahan yang sama telah berpaling kepada mekanisme pengendalian moneter melalui suku bunga sebagai sasaran operasional. Mekanisme ini didasarkan pada paradigma Keynesian bahwa transmisi kebijakan moneter ke sasaran akhir tidak secara langsung melalui perubahan volume uang beredar namun melalui perubahan suku bunga.

Dengan menggunakan analisis grafis dan pengujian ekonometri, studi ini menunjukkan adanya hubungan-hubungan kausalitas di antara beberapa variabel moneter yang sejalan dengan pendekatan Keynesian. Berdasarkan hubungan-hubungan tersebut serta didukung oleh hasil studi banding di Australia dan Selandia Baru, kami mencoba menawarkan konsep pengendalian moneter dengan suku bunga sebagai sasaran operasional untuk Indonesia.

Tulisan ini disajikan dengan rangkaian sebagai berikut. Bab "Evaluasi Atas Efektivitas Kebijakan Moneter" Selama Ini mengidentifikasi beberapa faktor yang dapat mempengaruhi efektivitas kebijakan moneter dan menjelaskan dampak deregulasi keuangan terhadap efektivitas kebijakan moneter selama ini. Bab "Suku Bunga sebagai Sasaran Operasional" mengulas secara ringkas teori yang melandasi mekanisme pengendalian moneter melalui suku bunga sebagai sasaran operasional dan merangkum pengalaman Australia dan Selandia Baru dalam menerapkan mekanisme tersebut. Bab "Kemungkinan Penggunaan Suku Bunga Sebagai Sasaran Operasional di Indonesia" menyajikan hasil studi empiris mengenai hubungan kausalitas antara suku bunga dan sasaran akhir kebijakan moneter (inflasi) serta jenis-jenis suku bunga yang dapat menjadi kandidat sasaran operasional kebijakan moneter. Selanjutnya, dalam Bab "Konsep Pengendalian Moneter Dengan Menggunakan Suku Bunga Sebagai Sasaran Operasional Untuk Indonesia" kami menyajikan konsep pengendalian moneter dengan menggunakan suku bunga sebagai sasaran operasional untuk Indonesia. Akhirnya, dalam Bab "Kesimpulan dan Saran" kami memberikan kesimpulan dan beberapa saran kebijakan serta arahan untuk penelitianpenelitian selanjutnya. 
Evaluasi Atas Efektivitas Kebijakan Moneter Selama Ini

\section{Faktor-faktor yang Mempengaruhi Efektivitas Kebijakan Moneter}

Kebijakan-kebijakan ekonomi secara garis besar dapat dibagi ke dalam dua kelompok, yaitu: kebijakan-kebijakan untuk mempengaruhi sisi penawaran agregat, seperti kebijakan ketenagakerjaan, kebijakan perdagangan, kebijakan perindustrian, dan kebijakan-kebijakan untuk mempengaruhi sisi permintaan agregat (atau lebih dikenal sebagai kebijakankebijakan ekonomi makro), seperti kebijakan moneter, fiskal, dan nilai tukar.

Seluruh kebijakan tersebut baik secara sendiri-sendiri maupun bersama-sama dapat mempengaruhi berbagai sasaran kebijakan ekonomi seperti laju inflasi, pertumbuhan ekonomi, dan keseimbangan neraca pembayaran. Oleh karena itu, dalam mengevaluasi suatu kebijakan idealnya kita harus mampu mengisolasi dampak kebijakan tersebut dari pengaruh kebijakan-kebijakan lain terhadap sasaran yang dituju.

Mengingat analisis ini ditujukan untuk menilai efektivitas kebijakan moneter dalam jangka pendek/menengah dan dengan keyakinan bahwa kebijakan di sisi penawaran lebih banyak berdampak terhadap perkembangan sasaran akhir dalam jangka panjang maka upaya mengevaluasi efektivitas kebijakan moneter dilakukan tanpa memperhitungkan pengaruh kebijakan-kebijakan di sisi penawaran.

Ada tiga komponen yang terkandung di dalam setiap kebijakan ekonomi, yaitu instrumen, sasaran, dan hubungan kausalitas antara instrumen dan sasaran (yang umumnya dipresentasikan ke dalam suatu model ekonomi). ${ }^{1}$ Uraian berikut ini akan mencoba mengidentifikasi faktor-faktor yang dapat mempengaruhi efektivitas kebijakan moneter dengan melihat kinerja ketiga komponen tersebut.

Dalam merancang kebijakan-kebijakan ekonomi untuk mencapai sasaran akhir berganda (multi-targeting), keharmonisan policy mix dan ketepatan policy assignment sangat penting. Landasan teoritis dari konsep kehamonisan policy mix dipelopori oleh pemenang hadiah Nobel di bidang Ilmu Ekonomi dari Belanda, Jan Tinbergen, sedangkan konsep ketepatan policy assigment diajukan oleh pakar ekonomi moneter internasional dari Amerika Serikat, Robert Mundell.

Kerangka kerja Tinbergen didasarkan pada asumsi adanya hubungan linear antara instrumen-instrumen kebijakan dengan sasaran-sasaran akhir. Salah satu syarat agar instrumen-instrumen kebijakan tersebut dapat mencapai sasaran-sasaran akhir yang berbeda secara bersamaan adalah jumlah instrumen yang tersedia minimal harus sama dengan jumlah sasaran akhir. Selain itu, setiap instrumen harus independen terhadap instrumen lain. (Lihat Lampiran). Di dalam kerangka kerja Tinbergen, penyebab ketidakefektivan kebijakan moneter dapat dilihat dari beberapa aspek, yaitu:

- Apakah jumlah instrumen kebijakan yang tersedia minimal sama dengan jumlah sasaran? Untuk kasus Indonesia, terdapat tiga sasaran utama kebijakan ekonomi makro yang ingin dicapai secara bersamaan, yaitu laju inflasi yang rendah, pertumbuhan ekonomi yang cukup tinggi, dan keseimbangan neraca pembayaran. Dari sisi permintaan, ketiga

1 Sach \& Larrain, "Macroeconomics in the Global Economy", hal. 589. 
sasaran tersebut diupayakan untuk dicapai dengan menggunakan tiga instrumen utama, yaitu kebijakan moneter, kebijakan fiskal, dan kebijakan nilai tukar. Dengan demikian, jumlah instrumen yang tersedia sudah sama dengan jumlah sasaran.

- Apakah terdapat pembatasan ruang gerak kebijakan moneter? Di Indonesia tampaknya tidak ada pembatasan secara eksplisit terhadap besaran-besaran moneter yang dikaitkan dengan kinerja sisi fiskal. Namun, tampaknya ruang gerak kebijakan moneter sangat dibatasi oleh sasaran nilai tukar.

- Apakah terdapat hubungan sebab akibat antara berbagai sasaran akhir? Hal ini tampaknya terjadi di Indonesia. Pencapaian sasaran pertumbuhan ekonomi seringkali harus mengorbankan pencapaian sasaran laju inflasi.

- Apakah policy mix cocok dengan policy setting? Di dalam sistem ekonomi terbuka dengan sistem nilai tukar yang relatif tetap seperti yang diterapkan oleh Indonesia sampai dengan 14 Agustus 1997, efektivitas kebijakan moneter sangat berkurang. Dalam situasi ini, pembebanan tugas yang terlalu berlebihan kepada kebijakan moneter untuk mencapai berbagai sasaran ekonomi makro hanya akan mendorong timbulnya ekonomi biaya tinggi (khususnya yang bersumber dari tingginya biaya suku bunga), mendorong masuknya modal asing berjangka pendek yang bermotif spekulasi, dan mendorong industri keuangan domestik untuk melakukan/ membiayai kegiatan usaha yang mengandung resiko tinggi.

Berkaitan dengan pembagian tugas di antara berbagai kebijakan yang tersedia, Robert Mundell mengajukan apa yang dikenal sebagai Mundell's Assignment Rule. Berdasarkan aturan tersebut, efektivitas setiap kebijakan tergantung pada kesesuaian pembagian tugas dengan keunggulan komparatif dari masing-masing kebijakan. Apabila kebijakan moneter diyakini lebih berpengaruh terhadap laju inflasi daripada kebijakan fiskal sedangkan kebijakan fiskal diyakini lebih berpengaruh terhadap pertumbuhan produksi daripada kebijakan moneter maka seyogianya kebijakan moneter hanya diberi tugas untuk mengendalikan laju inflasi sedangkan pengendalian produksi diserahkan sepenuhnya kepada kebijakan fiskal.

Efektivitas kebijakan moneter juga ditentukan oleh kemampuan otoritas moneter dalam mengendalikan instrumen-instrumen yang tersedia. Indikator yang paling sederhana adalah sejauh mana kemampuan otoritas moneter dalam mengendalikan uang primer. Terdapat beberapa faktor yang dapat mengurangi efektivitas pengendalian uang primer. Pertama, derasnya arus keluar masuk modal jangka pendek. Satu hasil penelitian menemukan bahwa koefisien ofset, yaitu koefisien yang mengukur pengaruh bersih operasi pasar terbuka (OPT) terhadap jumlah uang beredar, di Indonesia mencapai lebih dari 75\% (Bond, et al). Artinya, setiap Rp 1,00 jumlah uang yang disedot melalui OPT, hanya Rp 0,25 yang benar-benar berhasil disedot sedangkan sejumlah Rp 0,75 mengalir kembali ke masyarakat melalui peningkatan arus masuk modal dari luar negeri. Kedua, masih rendahnya tingkat kedalaman pasar uang (atau dalam kerangka analisis pemintaan dan penawaran kondisi ini tercemin pada kurva permintaan yang sangat tidak elastis). Saat ini tingkat kedalaman pasar uang baik rupiah maupun valuta asing masih relatif tipis. Dalam kondisi ini tekanan-tekanan baik yang bersumber dari pesatnya arus keluar masuk modal maupun tekanan likuiditas lebih banyak ditransmisikan melalui perubahan suku bunga dan nilai tukar daripada diredam oleh perubahan volume transaksi. Sebagai konsekuensinya suku bunga dan nilai tukar menjadi sangat fluktuatif. Ketiga, adanya 
segmentasi di sektor perbankan yang menimbulkan perbedaan perilaku di antara berbagai kelompok bank (contoh: antara kelompok bank-bank pemerintah dan kelompok bank-bank swasta) dalam menyikapi sinyal-sinyal kebijakan moneter. Keempat, rapuhnya sistem perbankan akibat praktek-praktek perbankan yang tidak berhati-hati dan sistem pengawasan yang lemah. Dengan kondisi portofolio yang buruk, walaupun ada kemauan, bank-bank tidak akan mampu memberikan respons kepada sinyal-sinyal kebijakan moneter.

Faktor lain yang tidak kalah pentingnya adalah tingkat kredibilitas yang dimiliki oleh otoritas pengambil kebijakan. Satu konsep yang berkaitan dengan kredibilitas pengambil kebijakan adalah konsep time consistency. Berdasarkan konsep ini, suatu kebijakan yang diambil berdasarkan prinsip discretionary akan mendorong para pengambil kebijakan untuk selalu mengambil kebijakan yang berbeda dengan ekspektasi pasar. Dari sisi pengambil kebijakan, tindakan ini adalah optimal karena mampu memaksimalkan manfaat dari kebijakan yang diambil. Namun, apabila tindakan tersebut dilakukan berkali-kali maka tingkat kredibilitas kebijakan akan turun di mata para pelaku pasar. Untuk Indonesia, masalah kredibilitas ini tampaknya perlu mendapat perhatian khusus. Seringkali kita amati bahwa berbagai sasaran ekonomi makro, khususnya sasaran-sasaran operasional kebijakan moneter, tidak mampu dicapai. Hal ini telah menurunkan kredibilitas kebijakan pemerintah dan mendorong masyarakat untuk membentuk ekspektasi yang berbeda dengan apa yang diinginkan oleh pemerintah.

Faktor lain yang dapat mempengaruhi efektivitas kebijakan moneter adalah adanya perubahan paradigma hubungan sebab akibat antara instrumen kebijakan dan sasaran akhir sebagai dampak dari deregulasi sektor keuangan dan meningkatnya keterkaitan antara pasar keuangan domestik dan internasional.

Berdasarkan uraian di atas, terdapat banyak kemungkinan faktor penyebab berkurangnya efektivitas kebijakan moneter. Namun, sebagaimana halnya pengalaman negara-negara lain ketika mereka menjalani proses transformasi ekonomi dan keuangan, faktor perubahan paradigma pengendalian moneter sebagai dampak deregulasi dan globalisasi di sektor keuangan diduga menjadi penyebab utama melemahnya kinerja kebijakan moneter di Indonesia. Oleh karena itu, ruang lingkup penelitian ini akan dibatasi pada upaya untuk menemukan mekanisme transmisi moneter dan kerangka operasional kebijakan moneter yang tepat untuk Indonesia di dalam konteks paradigma pengendalian moneter yang telah berubah.

\section{Dampak Deregulasi Keuangan terhadap Efektivitas Kebijakan Moneter}

Deregulasi dan globalisasi sektor keuangan membawa pengaruh yang besar terhadap perekonomian di banyak negara. Reformasi sektor keuangan yang dilakukan Indonesia dan beberapa negara ASEAN lainnya seperti Malaysia dan Thailand sejak dekade 1980-an telah meningkatkan efisiensi sektor keuangan dan menjadi salah satu faktor penting yang mendorong kemajuan ekonomi negara-negara tersebut. ${ }^{2}$

Di samping dampak positifnya terhadap perekonomian, perubahan yang cepat di pasar keuangan juga telah memberikan pengaruh negatif terhadap efektivitas kebijakan

2 The International Monetary Fund and the World Bank, Finance Development, March 1994 
moneter. Friedman mengidentifikasi tiga kemungkinan dampak deregulasi keuangan terhadap kebijakan moneter. Pertama, deregulasi suku bunga dan nilai tukar serta integrasi pasar-pasar keuangan di dunia akan mengubah proses transmisi kebijakan moneter. Kedua, inovasi-inovasi keuangan akan menyebabkan tidak stabilnya hubungan antara harga (inflasi) dan uang (besaran moneter). Ketiga, semakin meningkatnya mobilitas modal akan mempersulit pencapaian dua sasaran akhir, yaitu stabilitas harga dan stabilitas nilai tukar, dalam waktu bersamaan. ${ }^{3}$ Pengalaman di beberapa negara maju seperti Kanada, Australia, Selandia Baru, dan beberapa negara Eropa, serta hasil penelitian IMF menunjukkan bahwa setelah era reformasi sistem keuangan hubungan antara pertumbuhan uang beredar dan kegiatan ekonomi serta inflasi cenderung menjadi tidak stabil. ${ }^{4}$ Akibatnya, perkembangan jumlah uang beredar menjadi tidak mampu lagi memberikan indikasi arah perkembangan inflasi maupun produksi secara akurat. Kondisi tersebut menyebabkan banyak negara tidak lagi menggunakan besaran-besaran moneter sebagai variabel sasaran kebijakan moneter. Kini banyak negara menggunakan suku bunga dan nilai tukar sebagai sasaran operasionalnya.

Di Indonesia, kinerja pencapaian sasaran-sasaran moneter seperti M1 dan M2 cenderung menurun (lihat Grafik 1 dan 2). Kinerja pencapaian sasaran MO juga memiliki kecenderungan yang sama (lihat Grafik 3). Seiring dengan menurunnya kinerja pencapaian sasaran-sasaran moneter, kinerja pencapaian sasaran-sasaran akhir terutama laju inflasi dan neraca pembayaran tampak semakin sulit. Sasaran inflasi yang dalam Repelita V dan VI ditetapkan sebesar rata-rata 5\% per tahun tidak pernah berhasil dicapai. Defisit transaksi berjalan dalam tiga tahun terakhir semakin membengkak sementara struktur neraca modal semakin didominasi oleh modal jangka pendek yang mengandung resiko tinggi.

Gejala penurunan efektivitas kebijakan moneter tersebut tidak terlepas dari dampak deregulasi di sektor finansial yang telah dimulai sejak tahun 1983. Deregulasi tersebut telah mengakibatkan beberapa perubahan struktural. Pertama, pembebasan penentuan suku bunga kepada pasar menyebabkan terjadinya perubahan portofolio keuangan masyarakat yang tercemin dari perubahan komposisi uang kartal dan uang giral maupun komposisi simpanan berjangka dan uang giral. Kedua, batas antara MI dan M2 menjadi tipis karena semakin dekatnya substitusi antara uang kuasi khususnya tabungan (komponen M2) dengan M1. ${ }^{5}$ Ketiga, perubahan portofolio aset-aset keuangan mengakibatkan perubahan tingkat

Grafik 1: Sasarandan Realisasi M1 (\%)

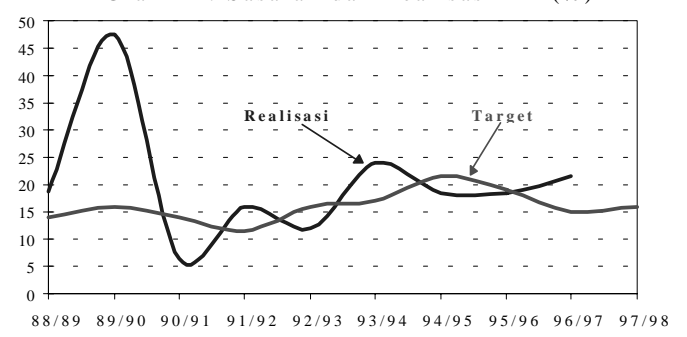

Grafik 2: Sasaran dan Realisasi M2 (\%)

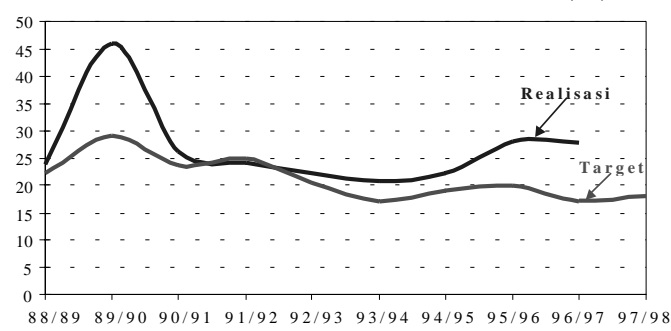

3 Morgan, Donald P., Introduction,...

4 Robert Dekle and Mahmood Pradhan, Financial Liberalization and Money Demand in ASEAN Countries : Implication for Monetary Policy.

5 Sarwono, Hartadi A.,Mencari Paradigma Baru Mekanisme Transmisi Sistem Pengendalian Moneter: Suatu Studi Kemungkinan Penerapannya, 1996 
Grafik 3: Sasaran dan Realisasi Uang Primer (\%)

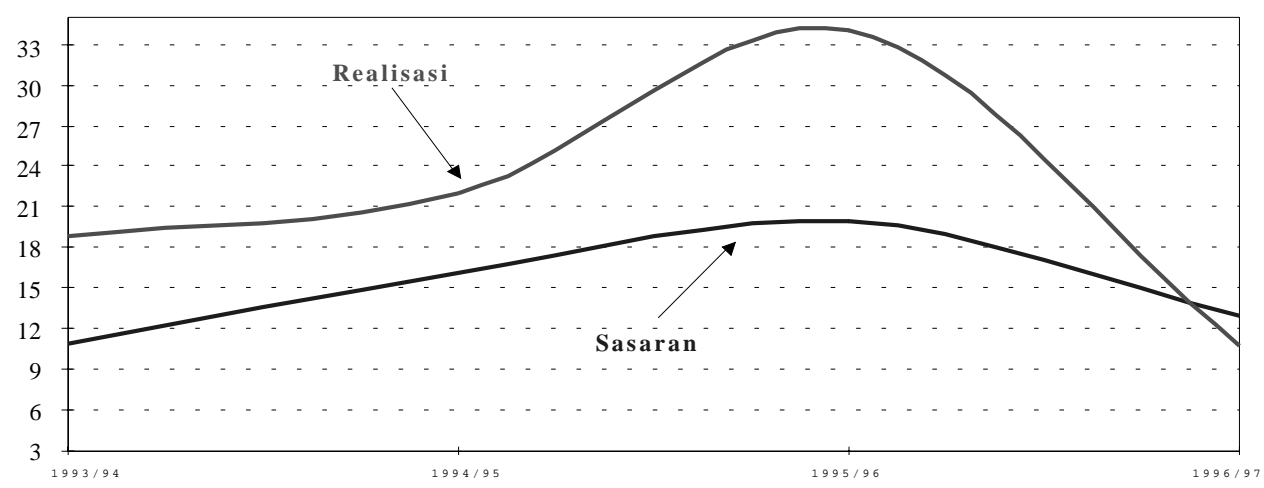

sensitivitas permintaan akan uang terhadap perubahan pendapatan dan suku bunga. Keempat, semakin berkembangnya pasar keuangan yang menawarkan beragam aset mempunyai pengaruh yang besar terhadap permintaan uang. ${ }^{6}$ Adanya banyak perubahan tersebut melahirkan sebuah keyakinan bahwa transmisi kebijakan moneter melalui harga uang (suku bunga) menjadi semakin penting dibandingkan dengan transmisi melalui jumlah uang beredar (kuantitas). ${ }^{7} \mathrm{Hal}$ ini juga didukung oleh hasil beberapa penelitian yang mempertanyakan kembali keyakinan yang melandasi kebijakan moneter Indonesia bahwa terdapat kestabilan angka pengganda uang dan permintaan akan uang serta keterkaitan yang erat antara besaran-besaran moneter dan sektor riil terutama PDB dan inflasi. ${ }^{8}$

\section{Suku Bunga Sebagai Sasaran Operasional}

\section{Landasan Teoritis: Sasaran Kuantitas vs. Sasaran Harga}

Kebijakan moneter dapat dilakukan melalui pengendalian jumlah uang beredar (sasaran kuantitas) atau suku bunga (sasaran harga). Pengendalian kuantitas dipelopori oleh aliran Monetaris sedangkan pengendalian suku bunga dipelopori oleh aliran Keynesian. Secara umum perbedaan antara Keynesian dan Monetaris dapat disederhanakan dalam bentuk elastisitasnya.

Aliran Monetaris percaya bahwa elastisitas suku bunga terhadap permintaan akan uang relatif rendah dan elastisitas suku bunga terhadap pemintaan barang relatif tinggi. Aliran ini berkeyakinan bahwa velocity of circulation dan uang beredar bersifat eksogen. Kondisi ini mengakibatkan uang tidak bersifat netral karena uang dapat mempengaruhi

6 Occasional Paper 84, Financial Liberalization, Money Demand, and Monetary Policy in Asian Countries, International Monetary Fund

7 Lihat catatan Direktur URES, Boediono "Merenungkan Kembali Mekanisme Transmisi Moneter di Indonesia”, Juni 1996

8 Penelitian terdahulu menyatakan bahwa permintaan M1 masih stabil. Namun penelitian ulang selanjutnya menyatakan bahwa keakuratan dan kestabilan permintaan akan uang tersebut perlu kehati-hatian dalam menginterpretasikan hasil proyeksi yang diperoleh. Lihat: Hartadi Sarwono dan Halim Alamsyah, "Sasaran Pengendalian Uang Beredar: Two Step Cointegration Approach", URES Discussion Paper, Bank Indonesia, September 1994 dan "Evaluasi terhadap Fungsi Permintaan Uang dan Program Moneter", Kertas Kerja Staf, Bagian APK, UREM, Juni , 1997. 
produksi dan harga dalam jangka pendek. Atas dasar asumsi-asumsi di atas maka aliran Monetaris lebih merekomendasikan penggunaan sasaran jumlah uang beredar daripada sasaran suku bunga.

Aliran Verticalist memiliki pemikiran yang sejalan dengan aliran Monetaris. Aliran ini meyakini bahwa, dengan asumsi money multiplier stabil dan dapat diperkirakan dengan baik, perubahan uang primer akan mempengaruhi komposisi neraca bank-bank (portofolio bank) yang pada gilirannya mempengaruhi kegiatan ekonomi. Dalam hal ini, perubahan uang primer (salah satu komponennya adalah bank reserve), akan diakomodasi oleh bank dengan mengubah komposisi asetnya, terutama kredit, atas inisiatif bank sendiri. Dalam grafik kuantitas versus harga dari uang beredar, kurva penawaran uang menjadi vertikal yang perubahannya dikendalikan oleh bank sentral, sedangkan suku bunga hanya mengikuti ke arah keseimbangan yang terjadi. ${ }^{9}$

Di lain pihak, aliran Keynesian percaya bahwa elastisitas suku bunga terhadap permintaan akan uang relatif tinggi sedangkan elastisitas suku bunga terhadap investasi relatif rendah. Aliran ini juga berkeyakinan bahwa velocity of circulation tidak stabil dan bergejolak dan uang beredar merupakan faktor endogen. Berbagai karakteristik pasar tersebut mengakibatkan mekanisme transmisi kebijakan moneter bersifat tidak langsung, yaitu melalui suku bunga. Oleh karena itu, aliran Keynesian merekomendasikan penggunaan sasaran suku bunga dalam melaksanakan kebijakan moneter.

Berikut ini adalah beberapa jalur transmisi kebijakan moneter dengan menggunakan sasaran suku bunga. ${ }^{10}$

- Intertemporal substitution. Perubahan suku bunga akan mengubah biaya pinjaman atau pendapatan dari tabungan. Hal ini selanjutnya akan berpengaruh terhadap komponen utama pengeluaran, terutama untuk investasi usaha, investasi perumahan, dan mungkin juga pengeluaran konsumsi barang-barang tahan lama.

- Exchange rate effect. Di dalam sistem nilai tukar mengambang, kenaikan suku bunga, ceteris paribus, biasanya akan dihubungkan dengan apresiasi nilai tukar dalam jangka pendek sehingga barang impor relatif menjadi lebih murah dan laju inflasi akan menurun. Kegiatan ekspor juga akan terpengaruh karena penjualan barang ekspor akan beralih ke dalam negeri. Pengalihan pasar produk ekspor ini juga akan mendorong turunnya hargaharga di dalam negeri.

- Cash-flow effect. Dengan meningkatnya suku bunga nominal, pendapatan nominal debitur akan menurun. Jika debitur menghadapi kendala likuiditas akibat meningkatnya suku bunga dan tidak dapat meminjam lagi dalam jumlah lebih besar untuk mempertahankan tingkat pengeluaran semula maka pengeluaran mereka terpaksa harus diturunkan.

- Wealth effect. Perubahan suku bunga yang biasa digunakan sebagai faktor diskonto dari ekspektasi pendapatan untuk masa yang akan datang akan mengubah nilai aset finansial dan aset riil. Perubahan nilai aset-aset tersebut mengakibatkan perubahan tingkat kesejahteraan pelaku ekonomi dan pada gilirannya akan mempengaruhi keputusan

9 Sarwono, Hartadi A., et.al.,Mencari Paradigma Baru Mekanisme Transmisi Sistem Pengendalian Moneter di Indonesia, Juli 1997, p.8

10 Stevens, Glen and Jenny Wilkinson, The monetary policy process in Australia: what do we know?, p.267-268 
konsumsi, investasi dan produksi.

- Credit rationing effect. Peningkatan suku bunga dapat mendorong bank-bank untuk meningkatkan premi resiko yang mereka bebankan kepada debitur lama maupun calon debitur baru akibat kekhawatiran akan turunnya kapasitas para debitur dalam membayar hutang-hutangnya. Implikasinya, suku bunga kredit meningkat, suplai kredit menurun, atau terjadi penjatahan kredit.

\section{Pengalaman Selandia Baru}

Untuk memperbaiki kinerja perekonomiannya yang relatif lebih buruk dibandingkan dengan negara-negara anggota OECD lainnya, sejak tahun 1984 Selandia Baru mulai melakukan serangkaian reformasi di sektor riil, fiskal, dan keuangan. Di sektor fiskal pemerintah melakukan pengurangan defisit anggaran secara bertahap sementara pembenahan di sektor riil dilakukan antara lain melalui penghapusan hambatan impor serta pengurangan tarif impor. Reformasi di sektor keuangan diawali dengan pembebasan penentuan tingkat suku bunga kepada pasar dan diikuti oleh deregulasi transaksi modal. Selanjutnya, sejak Maret 1985 Selandia Baru menerapkan sistem nilai tukar mengambang. Reformasi di sektor keuangan juga mencakup berbagai upaya penyempurnaan kebijakan moneter baik dari aspek kelembagaan, paradigma yang dianut, sasaran kebijakan moneter, maupun instrumen yang digunakan.

Di sisi kelembagaan, upaya penyempurnaan kebijakan moneter diawali dengan keluarnya Undang-undang Bank Sentral yang baru pada tahun 1989 yang secara formal dan konstitusional memberikan independensi kepada Bank Sentral dalam menjalankan tugas-tugasnya. Reformasi di sektor keuangan juga memaksa Selandia Baru untuk meninjau ulang paradigma pengendalian moneter yang sebelumnya mereka anut. Dalam perkembangannya, mereka memilih untuk menggunakan paradigma aliran Keynesian yang menjadikan suku bunga sebagai sasaran operasional pengendalian moneter. Di samping itu, sejak tahun 1985 Selandia Baru juga mengubah sasaran akhirnya menjadi sasaran tunggal yaitu stabilitas harga dengan menggunakan underlying inflation sebagai sasaran akhir. Untuk menentukan sasaran akhir, RBNZ menggunakan proyeksi inflasi berdasarkan teori Phillips curve dengan pendekatan output gap (selisih antara PDB aktual dan potensial) . Penetapan sasaran tersebut dilakukan melalui kesepakatan bersama antara Gubernur Bank Sentral (RBNZ) dengan Menteri keuangan yang disebut "the Policy Target Agreements (PTA)".

Untuk mencapai sasaran laju inflasi yang telah disepakati, RBNZ menetapkan sasaran operasional dan sasaran antara. Sebagai sasaran operasional, RBNZ mengendalikan likuditas perbankan (cash settlement) pada level tertentu (saat ini sekitar \$5 juta per hari ). Apabila level settlement cash tidak sesuai dengan sasaran yang ditetapkan, pada kondisi likuditas ketat RBNZ akan membeli govermment bills di pasar uang melalui OPT dan menjualnya pada kondisi longgar. Upaya pengendalian cash settlement akan mempengaruhi tingkat suku bunga cash rate dan selanjutnya akan mempengaruhi suku bunga treasury bill 90 hari.

Sebagai sasaran antara, RBNZ menggunakan variabel proksi yang disebut Monetary Conditions Indicator (MCI) . MCI adalah indikator yang menggabungkan pengaruh moneter yang berasal dari suku bunga (treasury bill 90 hari) dan nilai tukar (trade weighted index). 


\section{Pengendalian Moneter di Selandia Baru}

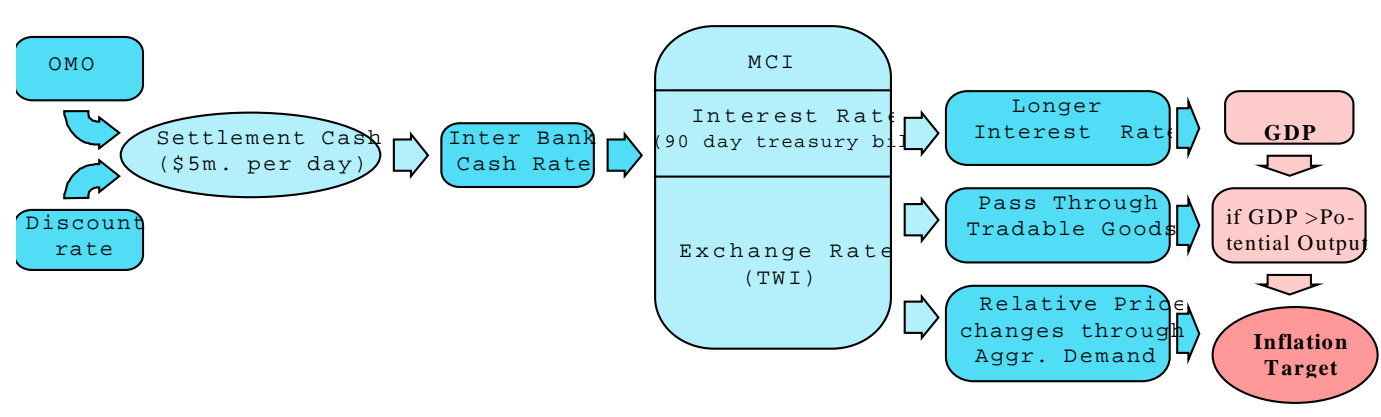

Sementara itu, besaran-besaran moneter hanya digunakan sebagai variabel indikator.

Dari skema di bawah ini terlihat bahwa pengendalian moneter di Selandia Baru dilakukan melalui upaya Bank Sentral untuk mempengaruhi suku bunga antarbank. Perubahan suku bunga antarbank tersebut diharapkan akan mempengaruhi suku bunga treasury bill 90 hari dan nilai tukar. Perubahan suku bunga treasury bill 90 hari akan ditransmisikan ke sektor riil melalui dampaknya terhadap PDB. Apabila PDB aktual melebihi PDB potensial (output gap), inflasi akan cenderung naik. Sementara itu, perubahan nilai tukar dapat mempengaruhi PDB dan akhimya laju inflasi melalui dua saluran, yaitu :

- Melalui tradbable goods. Proses transmisi ini memerlukan lag sekitar 4-6 kuartal. Setiap depresiasi 1\% akan menaikkan inflasi sebesar 0,3\%.

- Melalui permintaan aggregat. Mekanisme ini memerlukan lag yang lebih panjang yaitu sekitar 2 tahun.

\section{Pengalaman Australia}

Mengiringi deregulasi keuangan yang dimulai sejak akhir 1970-an, kebijakan moneter di Australia terus mengalami berbagai penyesuaian. Sejak tahun 1985, kerangka kebijakan moneter berubah dari pengendalian moneter yang menggunakan besaran moneter sebagai sasaran antara menjadi suku bunga sebagai sasaran antara. Hal ini antara lain berkaitan dengan sulitnya mengendalikan jumlah uang beredar sehubungan dengan makin sulitnya memprediksi besaran-besaran moneter akibat banyaknya inovasi di sektor keuangan. Perkembangan ini mengakibatkan permintaan akan uang menjadi tidak stabil dan hubungan antara besaran moneter dengan sasaran akhir menjadi kurang signifikan. Untuk meningkatkan efektivitas dan kredibilitas kebijakan moneter, prioritas sasaran akhir adalah menciptakan laju inflasi yang rendah yang dituangkan ke dalam sasaran laju inflasi underlying $2 \%-3 \%$ per tahun.

Pengendalian moneter dilakukan melalui operasi pasar terbuka dengan jalan menetapkan suku bunga ovemight funds (cash rates). Cash rates ini menjadi sasaran operasional kebijakan moneter. Apabila RBA akan melakukan perubahan arah kebijakan moneter maka RBA akan melakukan operasi pasar untuk mempengaruhi cash rate. Perubahan cash rate akan segera diikuti oleh perubahan berbagai suku bunga lainnya khususnya suku bunga pinjaman dan suku bunga lainnya yang berjangka waktu lebih panjang. Selanjutnya, 


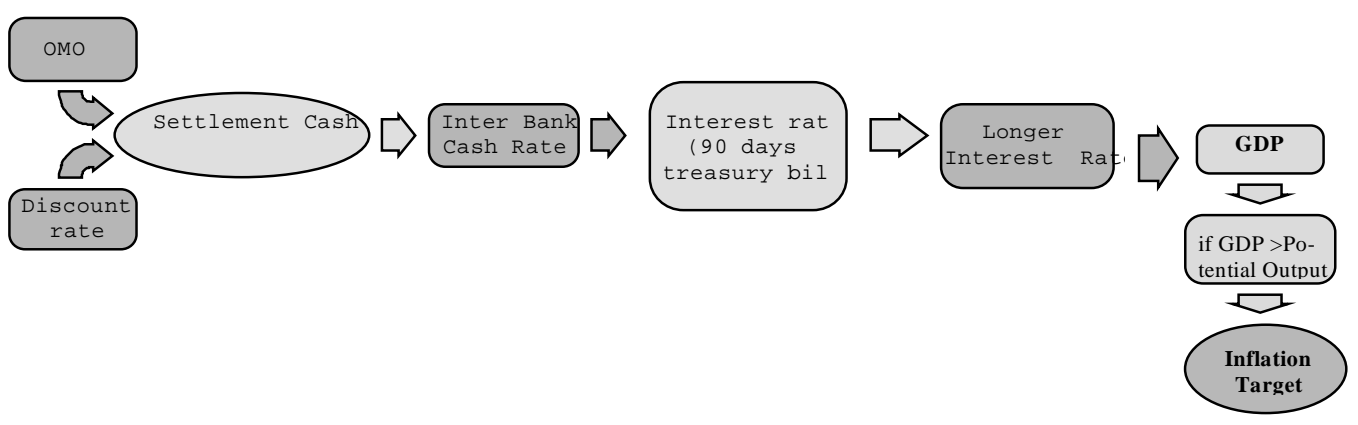

perubahan suku bunga berjangka waktu panjang diharapkan akan mempengaruhi output gap dan laju inflasi. Skema berikut menggambar mekanisme transmisi kebijakan moneter di Australia.

Pada dasarnya cash rates akan bergerak bebas sesuai dengan kekuatan permintaan dan penawaran di pasar uang. Untuk menjaga agar cash rate tetap berada pada tingkat yang telah ditetapkan, RBA melakukan operasi pasar dengan menggunakan instrumen surat berharga pemerintah yang terdiri atas Commonwealth Government Securities dan State Govermment Secunities. Sejak Januari 1990 RBA mengumumkan tingkat cash rate harian yang akan dicapai pada hari tersebut berikut latar belakang kenaikan atau penurunannya. Kredibilitas RBA merupakan faktor yang sangat menentukan karena "announcement effect" yang kuat menyebabkan bank-bank berupaya untuk mengajukan "bid/offer rate" sedekat mungkin berdasarkan keyakinan bahwa RBA akan masuk ke pasar untuk memastikan bahwa sasaran cash rate akan tercapai.

(\%)

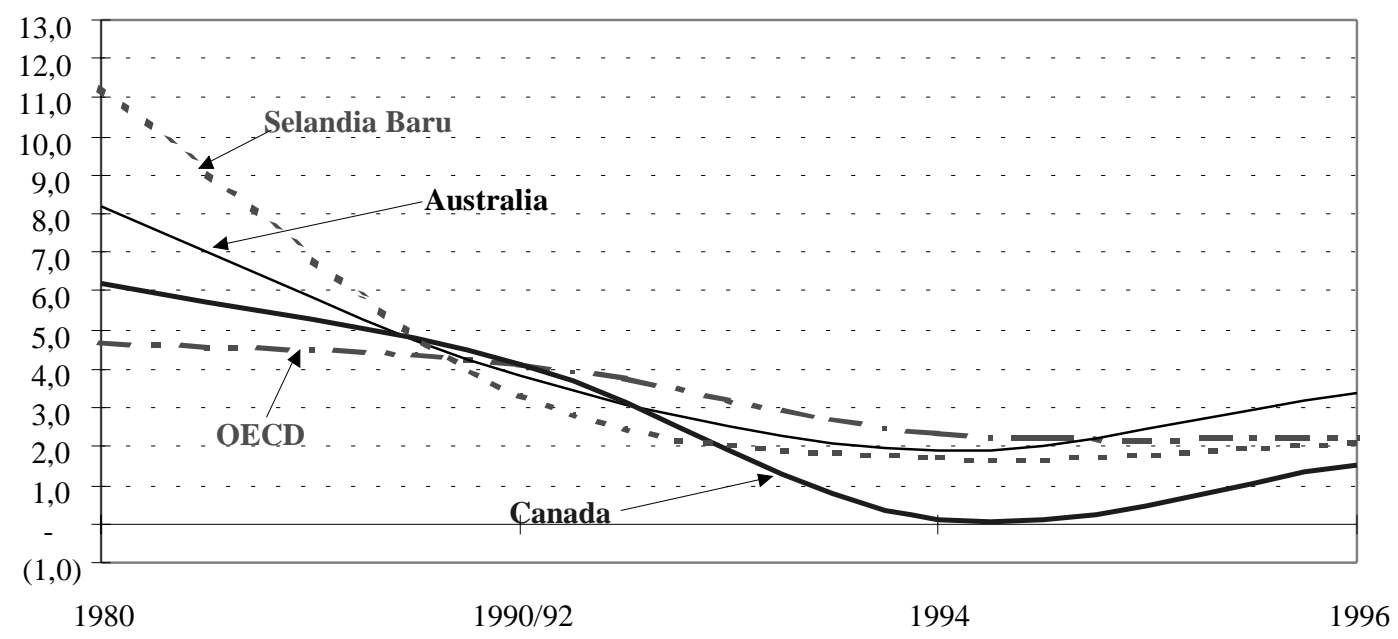


Berdasarkan pengalaman beberapa negara yang menggunakan suku bunga sebagai sasaran qperasional dan laju inflasi underlying sebagai sasaran akhir, pada umumnya mereka berhasil menurunkan laju inflasi baik dalam ukuran CPI maupun inflasi underlying secara mengesankan. Sebagai contoh, dalam tahun 1980-an Selandia Baru dan Australia masing-masing mengalami inflasi rata-rata sebesar 11,3\% dan 8,2\%. Namun, setelah kedua negara menerapkan inflation targeting dan menggunakan suku bunga sebagai sasaran operasional pengendalian moneter, laju inflasi berhasil diturunkan menjadi 1,7\% dan 1,9\% pada tahun 1994.

Kemungkinan Penggunaan Suku Bunga Sebagai Sasaran Operasional Di Indonesia

\section{Proses Transmisi Sasaran Antara ke Sasaran Akhir}

Sebagai langkah pertama dalam melihat kemungkinan penggunaan suku bunga sebagai sasaran operasional dalam pengendalian moneter, perlu kiranya dicari jenis suku bunga yang dapat berperan sebagai sasaran antara, yaitu suku bunga yang mampu mentransmisikan sinyal-sinyal yang diberikan oleh kebijakan moneter ke sasaran akhir, dalam hal ini laju inflasi. Dengan menggunakan tes kausalitas Granger menggunakan data bulanan dalam periode setelah deregulasi 1988 (1989.1-1997.7) dapat dinyatakan halhal berikut (hasil pengujian di dalam Tabel 1):

Tabel 1

Hasil Tes Kausalitas Granger Antara Suku Bunga dan Laju Inflasi

\begin{tabular}{|lllll|}
\hline \multicolumn{3}{|c}{ Hipotesis } & F Stat. & Prob. \\
\hline Dep. 1 & $\Rightarrow$ & Inflasi & 3.43 & 0.04 \\
Inflasi & $\Rightarrow$ & Dep.1 & 1.44 & 0.24 \\
Dep. 3 & $\Rightarrow$ & Inflasi & 1.53 & 0.22 \\
Inflasi & $\Rightarrow$ & Dep.3 & 0.69 & 0.51 \\
Dep. 6 & $\Rightarrow$ & Inflasi & 1.43 & 0.24 \\
Inflasi & $\Rightarrow$ & Dep.6 & 0.24 & 0.79 \\
Dep. 12 & $\Rightarrow$ & Inflasi & 0.00 & 0.99 \\
Inflasi & $\Rightarrow$ & Dep.12 & 1.88 & 0.16 \\
KI & $\Rightarrow$ & Inflasi & 0.34 & 0.71 \\
Inflasi & $\Rightarrow$ & KI & 0.36 & 0.70 \\
K M K & $\Rightarrow$ & Inflasi & 2.30 & 0.08 \\
Inflasi & $\Rightarrow$ & K M K & 0.65 & 0.59 \\
\hline
\end{tabular}

Catatan: Masing-masing variabel menggunakan bentuk first difference.

- Suku bunga deposito berjangka 1 bulan mempunyai hubungan searah dengan inflasi. Hal ini berarti bahwa inflasi dipengaruhi oleh pergerakan suku bunga deposito 1 bulan. Di samping itu, suku bunga kredit modal kerja (KMK) juga mempunyai hubungan yang searah dengan inflasi. 
Grafik 5: Proporsi Deposito Menurut Jangka V

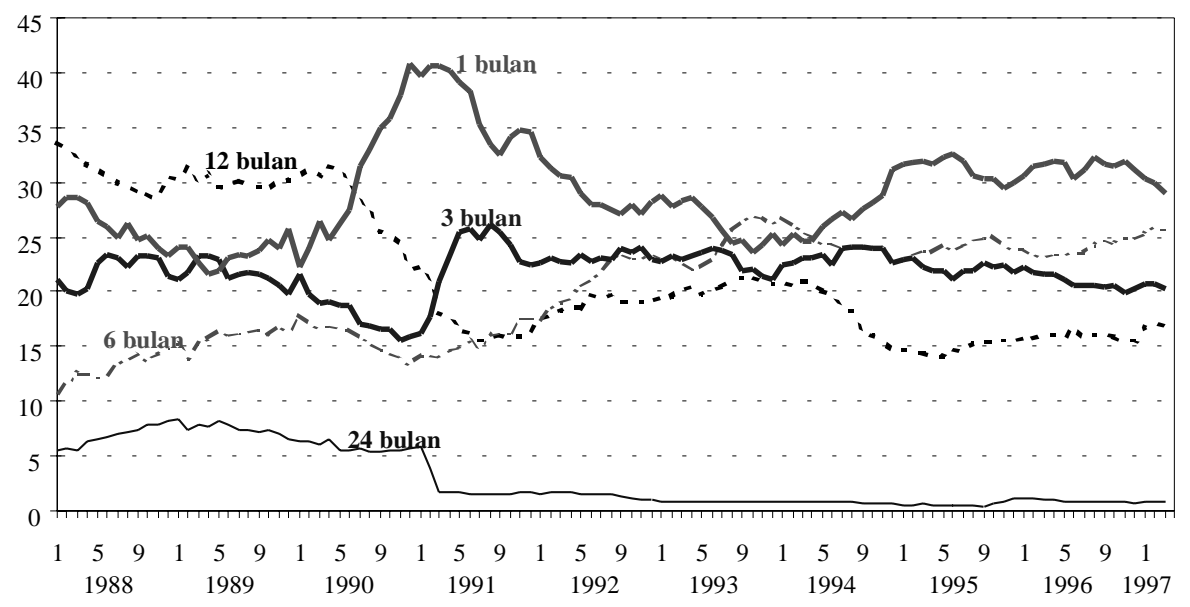

- Suku bunga deposito yang berjangka lebih panjang, yaitu yang berjangka 3, 6, dan 12 bulan tidak mempengaruhi laju inflasi.

Keterkaitan yang cukup kuat antara suku bunga deposito satu bulan dan laju inflasi sejalan dengan semakin besarnya peranan deposito satu bulan dalam total dana yang dihimoun oleh perbankan (lihat Grafik 5). Sejak tahun 1990 tampak ada pergeseran dalam preferensi masyarakat dalam memegang deposito, yaitu dari deposito yang berjangka relatif panjang, khususnya deposito 12 bulan, ke deposito yang berjangka waktu sangat pendek yaitu deposito berjangka satu bulan. Perubahan preferensi mungkin disebabkan oleh tingginya suku bunga deposito berjangka waktu pendek dibandingkan dengan yang berjangka waktu lebih panjang akibat kesulitan likuiditas yang dialami oleh perbankan. Kalau benar demikian maka hasil yang diperoleh dari pengujian ini mungkin saja berubah apabila bank-bank tidak lagi mengalami kesulitan likuiditas.

Selanjutnya untuk melihat kemungkinan adanya hubungan jangka panjang antara suku bunga deposito satu bulan dan laju inflasi dilakukan uji Kointegrasi Johansen. Hasil pengujian tersebut menunjukkan bahwa, dengan tingkat keyakinan 5\%, terdapat hubungan yang bersifat jangka panjang antara suku bunga deposito satu bulan dengan laju inflasi. Hasil pengujian dapat dilihat pada tabel berikut:

Tabel 2

Uji Kointegrasi Johansen: Suku Bunga Deposito Satu Bulan dan Laju Inflasi

Sampel : 1989:01 1997:07

Jumlah Observasi : 98

Series : DEP1 TNEL

\begin{tabular}{lcccc} 
Eigenvalue & $\begin{array}{c}\text { Likelihood } \\
\text { Ratio }\end{array}$ & $\begin{array}{c}5 \text { Percent } \\
\text { Critical Value }\end{array}$ & $\begin{array}{c}1 \text { Percent } \\
\text { Critical Value }\end{array}$ & $\begin{array}{c}\text { Hypothesized } \\
\text { No. of CE (s) }\end{array}$ \\
\hline 0.07120 & 11.35990 & 15.41 & 20.04 & None \\
0.041176 & 4.120647 & 3.76 & 6.65 & At most 1* \\
\hline
\end{tabular}

(*) menunjukkan penolakan hipotesis nol pada tingkat signifikansi 5\%.
Asumsi : Linear deterministic trend in the data Lags interval : 1 to 4 
Proses Transmisi Sasaran Operasional ke Sasaran Antara

Setelah diperoleh kandidat terkuat sasaran antara kebijakan moneter Indonesia, yaitu suku bunga deposito satu bulan, langkah selanjutnya adalah mencari variabel yang dapat menjadi sasaran operasional. Sasaran operasional pada umumya adalah variabel yang mampu mencerminkan kondisi likuiditas di pasar uang sekaligus dapat dipengaruhi oleh berbagai instrumen kebijakan moneter. Di pasar uang Indonesia, variabel yang diperkirakan memenuhi syarat-syarat di atas adalah suku bunga PUAB.

Secara visual, suku bunga PUAB (rata-rata seluruh jangka waktu 1 s.d. 90 hari) tampaknya menunjukkan pergerakan yang searah dengan suku bunga deposito berjangka (Grafik 6 dan 7). Perkembangan yang searah tersebut juga terjadi antara suku bunga PUAB dengan suku bunga kredit baik KMK maupun KI (Grafik 8).

Grafik 6: Suku Bunga Dep. 1 Bulan, Dep. 3 Bulan, dan PUAB

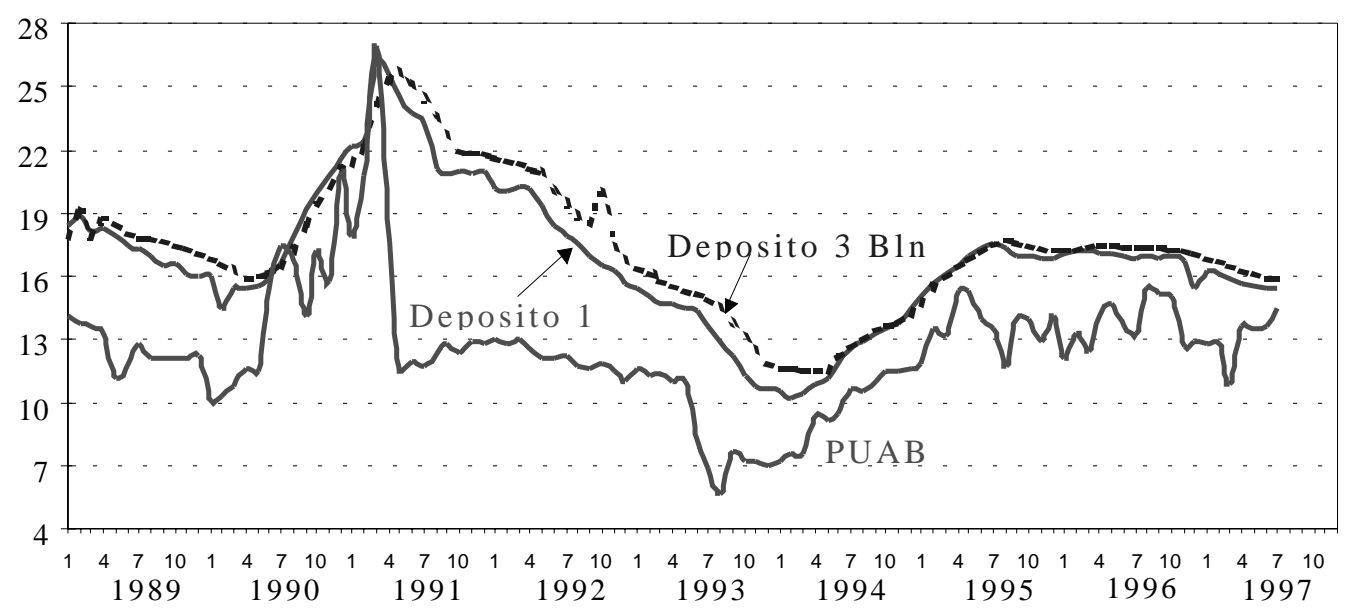

Grafik 7: Suku Bunga Dep. 6 Bulan, Dep. 12 Bulan, dan PUAB

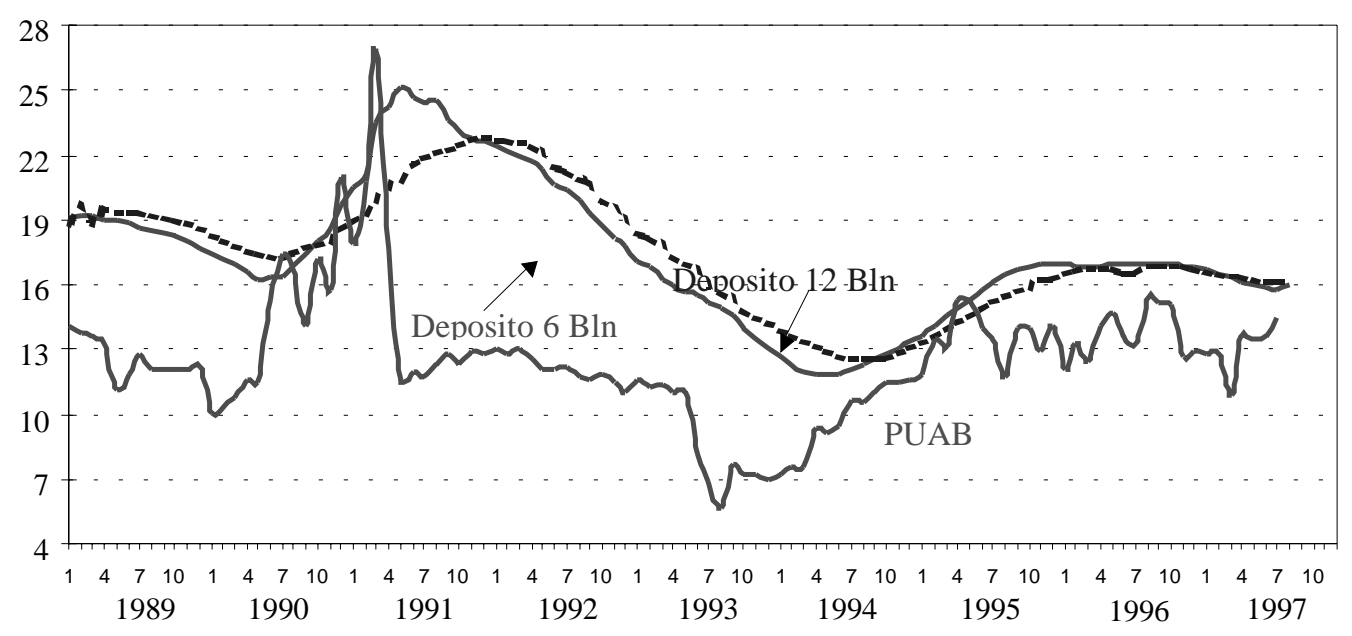


Grafik 8: Suku Bunga Kredit Modal Kerja, Kredit Investasi, dan PUAB

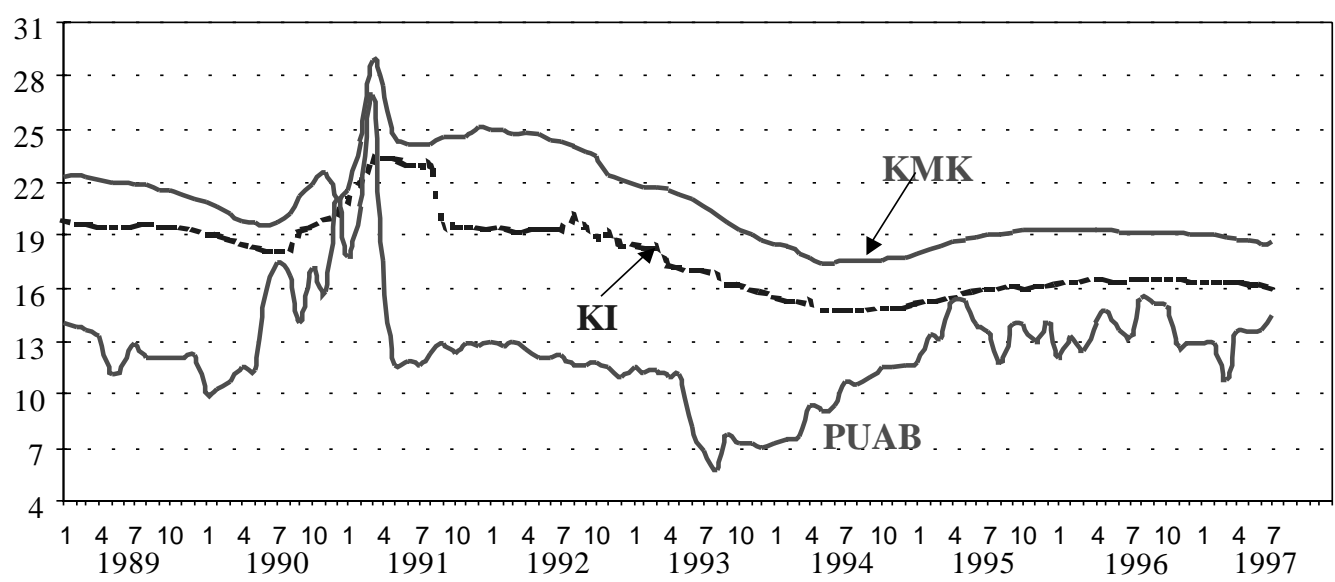

Untuk memperoleh indikasi arah hubungan antara suku bunga PUAB dengan suku bunga deposito, kredit modal kerja, dan kredit investasi, telah dilakukan pengujian Granger atas variabel-variabel tersebut. Dari Tabel 3 dapat disimpulkan bahwa suku bunga PUAB mempunyai hubungan yang searah dengan suku bunga deposito 1 bulan, 3 bulan, 6 bulan, dan kredit investasi (KI). Sementara itu, terdapat hubungan dua arah antara suku bunga PUAB dan suku bunga kredit modal kerja (KMK)

Tabel 3

Hasil Tes Kausalitas Granger: Suku Bunga PUAB, Deposito, KMK, dan KI

\begin{tabular}{|lllll|}
\hline \multicolumn{3}{c}{ Hipotesis } & F Stat. & Prob. \\
\hline P UAB & $\Rightarrow$ & Dep.1 & 8,25 & 0,00 \\
Dep.1 & $\Rightarrow$ & P UAB & 1,23 & 0,30 \\
P UAB & $\Rightarrow$ & Dep.3 & 3,52 & 0,03 \\
Dep.3 & $\Rightarrow$ & P UAB & 1,09 & 0,34 \\
P UAB & $\Rightarrow$ & Dep.6 & 7,65 & 0,00 \\
Dep.6 & $\Rightarrow$ & P UAB & 1,86 & 0,16 \\
P UAB & $\Rightarrow$ & Dep.12 & 0,12 & 0,89 \\
Dep.12 & $\Rightarrow$ & P UAB & 0,46 & 0,63 \\
P UAB & $\Rightarrow$ & KI & 4,06 & 0,00 \\
KI & $\Rightarrow$ & P UAB & 0,42 & 0,83 \\
P UAB & $\Rightarrow$ & K M K & 15,74 & 0,00 \\
K M K & $\Rightarrow$ & P UAB & 12,19 & 0,00 \\
\hline
\end{tabular}

Catatan: Masing-masing variabel menggunakan bentuk first difference.

Untuk lebih memahami mekanisme transmisi suku bunga PUAB ke suku bunga deposito perlu dikembangkan suatu model suku bunga. Untuk suatu perekonomian yang 
terbuka maka suku bunga pasar dipengaruhi oleh dua faktor yaitu faktor internal dan eksternal (Edward, et.al.,1985) . Hubungan tersebut dapat dinyatakan sebagai berikut:

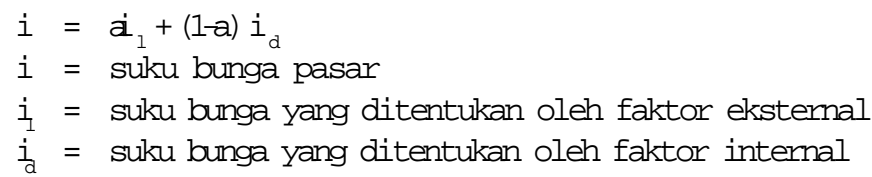

Secara umum ada dua cara dalam merumuskan model penentuan suku bunga yang dipengaruhi oleh faktor ekstemal, yaitu uncovered interest parity (UIP) dan covered interest parity (CIP).

Model UIP dapat diformulasikan sebagai berikut:

$$
i=i^{\star}+e
$$

Sedangkan model CIP:

$$
i=i^{\star}+e+r_{p}
$$

dimana:

$$
\begin{aligned}
& \mathbb{F}=\text { suku bunga di luar negeri } \\
& e=\text { ekspektasi depresiasi } \\
& r_{p}=\text { premi resiko }
\end{aligned}
$$

Dengan dibukanya kisaran nilai tukar intervensi sejak 14 Agustus 1997 maka faktor resiko perubahan nilai tukar menjadi sangat penting. Sehingga model CIP dapat diubah menjadi:

$i=i^{\star}+f_{d}$, dimana $f_{d}=$ premi forward.

Formula suku bunga paritas di atas dapat dikembangkan untuk mengetahui proses transmisi perubahan suku bunga PUAB ke suku bunga pasar berjangka menengah dan panjang. Model pengembangan tersebut sebagai berikut:

$$
R \text { puab }=a+b \text { SBI/SBPU }+e
$$

interest rate $=a+b$ PUAB $+e^{11}$ Q

Jika proses transmisi berlangsung sangat cepat dan komplet maka b akan mendekati 1 . Akan tetapi untuk suku bunga yang berjangka relatif lebih panjang proses transmisi berlangsung lebih lambat sehingga perlu ada faktor lag.

interest rate $_{\mathrm{t}}=\mathrm{a}+\mathrm{Sg}_{\mathrm{i}} \mathrm{DPUAB}+\mathrm{Sl}_{\mathrm{i}}$ Dinterest rate $_{\mathrm{ti}}+\mathrm{b} \mathrm{PUAB}+\mathrm{et}$

Faktor yang mempengaruhi cepat/lambatnya proses transmisi antara lain adalah struktur dari simpanan masyarakat di bank dan bunganya, tingkat resiko dari pinjaman yang diberikan bank, dan tingkat persaingan bank.

Dengan anggapan bahwa suku bunga pasar, misal deposito, tidak hanya ditentukan oleh perkembangan suku bunga deposito itu sendiri dari waktu-waktu sebelumnya tetapi

11 Diadaptasi dari Lowe, Philip, The link between the cash rate and market interest rate, RBA, p. 4-5 
juga merupakan respons dari perubahan suku bunga luar negeri dan ekspektasi depresiasi, diperoleh model suku bunga sbb:

interest rate ${ }_{t}=a_{1}+S_{i} D P U A B+a_{2} i_{t}+b$ PUAB

dimana 1 = suku bunga libor + ekspektasi depresiasi. ${ }^{12}$

$\mathrm{b}=$ long-run response dari perubahan interest rate terhadap perubahan pada sukubunga qperating target.

Atas dasar model di atas, dilakukan pengetesan untuk melihat kecepatan transmisi dan kekuatan pengaruh perubahan suku bunga PUAB (Lihat Tabel 4). Dengan melakukan sedikit transformasi atas hasil persamaan regresi tersebut, dapat dihitung besarnya koefisien b, yaitu 0,84. Angka koefisien b yang cukup besar tersebut menunjukkan bahwa proses transmisi suku bunga PUAB ke suku bunga deposito 1 bulan berlangsung cukup cepat.

Tabel 4

\begin{tabular}{|c|c|c|c|c|}
\hline \multicolumn{5}{|c|}{$\begin{array}{l}\text { LS // Dependent Variable is DDEP1 } \\
\text { Sample: 1992:04 1997:07 } \\
\text { Included observations: } 64 \text { after adjusting endpoints }\end{array}$} \\
\hline Variable & Coefficient & Std. Error & T-Statistic & Prob. \\
\hline $\mathrm{C}$ & 0,6888 & 0,2344 & 2,9380 & 0,0049 \\
\hline PUAB (-1) & 0,1151 & 0,0341 & 3,3698 & 0,0014 \\
\hline $\mathrm{D}(\mathrm{PUAB}, 2)$ & 0,1770 & 0,0819 & 2,1594 & 0,0354 \\
\hline $\mathrm{D}(\mathrm{PUAB}, 3)$ & $-0,1167$ & 0,0565 & $-2,0682$ & 0,0435 \\
\hline DPUAB $(-2)$ & 0,1784 & 0,0756 & 2,3613 & 0,0219 \\
\hline DPUAB $(-5)$ & 0,0763 & 0,0384 & 1,9868 & 0,0521 \\
\hline $\operatorname{DEP} 1(-1)$ & $-0,1370$ & 0,0306 & $-4,4734$ & 0,0000 \\
\hline $\operatorname{DER}(-1)$ & 0,0002 & 0,0001 & 3,3592 & 0,0015 \\
\hline $\operatorname{DDEP} 1(-2)$ & 0,1481 & 0,0951 & 1,5575 & 0,1253 \\
\hline DDEP1 $(-4)$ & 0,1781 & 0,0982 & 1,8133 & 0,0755 \\
\hline DLIB1 (-2) & 0,1587 & 0,1365 & 1,1625 & 0,2502 \\
\hline R-squared & 0,6984 & \multicolumn{2}{|c|}{ Mean dependent var. } & $-0,0763$ \\
\hline Adjusted R-squared & 0,6415 & \multicolumn{2}{|c|}{ S.D. dependent var. } & 0,4449 \\
\hline S.E. of regression & 0,2664 & \multicolumn{2}{|l|}{ F-statistic } & 12,2755 \\
\hline DW-stat & 1,8709 & \multicolumn{2}{|c|}{ Prob (F-statistic) } & 0,0000 \\
\hline
\end{tabular}

12 Pada dasarnya ada beberapa pendekatan untuk menghitung ekspektasi depresiasi, antara lain pendekatan rational expectation, adaptive expectation dan bisa juga menggunakan penyimpangan antara nilai tukar PPP dengan nilai tukar aktual. Akan tetapi dalam makalah ini diasumsikan bahwa nilai aktual sama besarnya dengan nilai ekspektasinya. Untuk masa yang akan datang, peranan ekspektasi nilai tukar ini semakin penting sehingga perlu pengkajian yang lebih mendalam. 
Hubungan antara Sasaran Operasional dan Instrumen Kebijakan Moneter

Langkah berikutnya adalah mencari instrumen kebijakan moneter yang mampu mempengaruhi pergerakan sasaran operasional. Secara visual baik suku bunga SBI maupun SBPU memiliki pergerakan yang searah dengan suku bunga PUAB (Grafik 9). SBI yang berjangka waktu 7 hari relatif lebih dekat daripada SBI yang berjangka waktu 1 bulan. Perkembangan suku bunga SBPU juga terlihat searah dengan suku bunga PUAB sampai periode 1994. Setelah itu, suku bunga SBPU relatif konstan (Grafik 10).

Hasil uji kausalitas Granger antara suku bunga PUAB, suku bunga SBI 7 hari dan 1 bulan, dan suku bunga SBPU 7 hari dan 1 bulan memberikan hasil-hasil berikut (lihat Tabel 5) :

- Suku bunga SBI 7 hari maupun yang berjangka waktu 1 bulan tidak mempunyai hubungan baik searah maupun dua arah dengan suku bunga PUAB. Berarti suku bunga PUAB tidak ditentukan oleh perubahan suku bunga SBI dan begitu juga suku bunga SBI tidak dipengaruhi oleh suku bunga PUAB.

Grafik 9: Suku Bunga SBI 7 Hari, SBI 1 Bulan, dan PUAB

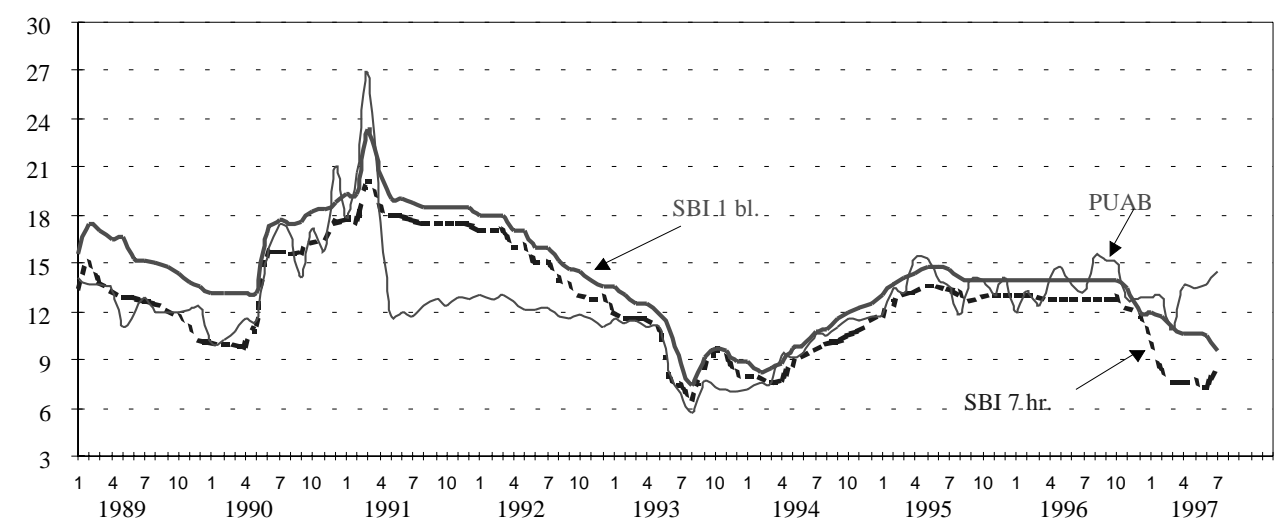

Grafik 10: Suku Bunga SBPU 7 Hari. SBPU 1 Bulan. dan PUAB

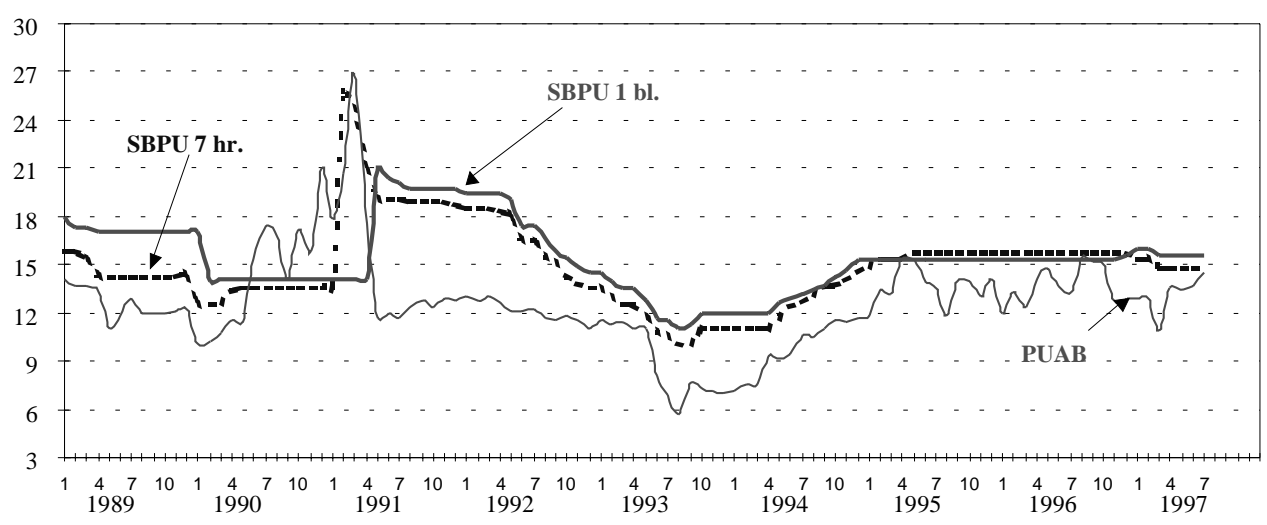


- Akan tetapi suku bunga SBPU 7 hari mempunyai hubungan kausalitas yang bersifat dua arah dengan suku bunga PUAB. Dengan perkataan lain, suku bunga SBPU 7 hari mempengaruhi suku bunga PUAB dan sebaliknya suku bunga PUAB mempengaruhi suku bunga SBPU 7 hari.

Tabel 5

Uji Kausalitas Granger: Suku Bunga PUAB, SBI, dan SBPU

\begin{tabular}{|lllll|}
\hline \multicolumn{2}{|c|}{ Hipotesis } & & F Stat. & Prob. \\
\hline SBI 1 & $\Rightarrow$ & P U A B & 0,41 & 0,66 \\
P U A & $\Rightarrow$ & SBI 1 & 0,81 & 0,45 \\
& & & & \\
SBI 7 & $\Rightarrow$ & P UAB & 1,60 & 0,21 \\
P U A & $\Rightarrow$ & SBI 7 & 0,53 & 0,59 \\
& & & & \\
SBPU 1 & $\Rightarrow$ & P UAB & 0,42 & 0,66 \\
P UAB & $\Rightarrow$ & SBPU 1 & 12,42 & 0,00 \\
SBPU 7 & $\Rightarrow$ & P UAB & 28,83 & 0,00 \\
P UAB & $\Rightarrow$ & SBPU 7 & 4,86 & 0,01 \\
\hline
\end{tabular}

Catatan: Masing-masing variabel menggunakan bentuk first difference.

Kenapa suku bunga PUAB lebih dekat hubungannya dengan suku bunga SBPU daripada dengan suku bunga SBI? Salah satu kemungkinan alasannya adalah instrumen SBPU digunakan oleh bank-bank untuk mencari dana sehingga suku bunga SBPU lebih mencerminkan harga dari kelangkaan dana. Alasan lain terkait dengan adanya perbedaan mekanisme lelang antara kedua instrumen OPT tersebut.

Sejak April 1993 sistem yang diterapkan untuk lelang SBI adalah Stop out Rate (SOR) atau sistem target kuantitas. Selain penjualan SBI secara lelang, Bank Indonesia juga melakukan penjualan SBI secara intervensi. Dalam intervensi tingkat diskonto terlebih dahulu ditetapkan oleh Bank Indonesia berdasarkan tingkat bunga di pasar yang bisa berada di atas atau di bawah suku bunga SBI lelang. Ada kemungkinan bahwa suku bunga SBI intervensi juga mempunyai hubungan yang erat dengan suku bunga PUAB karena penentuan suku bunga SBI intervensi lebih mengarah ke tingkat harga dana di pasar dibandingkan dengan suku bunga SBI lelang. Sementara itu, lelang SBPU menganut sistem cut Off Rate (COR) atau sistem target suku bunga.

Konsep Pengendalian Moneter Dengan Menggunakan Suku Bunga Sebagai Sasaran Operasional Untuk Indonesia

\section{Penggunaan Sasaran Akhir Tunggal}

Kebijakan moneter di Indonesia mempunyai sasaran ganda, yaitu: (1) pertumbuhan ekonomi yang tinggi, (2) penyediaan lapangan kerja yang cukup, (3) laju inflasi yang rendah 
dan (4) neraca pembayaran yang mantap. Dalam pelaksanaannya sulit bagi bank sentral untuk mencapai seluruh sasaran tersebut dalam waktu yang sama karena adanya "conflicting target" antara satu sasaran dengan sasaran lainnya.

Untuk meningkatkan efektivitas kebijakan moneter perlu kiranya dipertimbangkan penggunaan sasaran akhir tunggal. Kalau pun sasaran ganda masih dipertahankan maka perlu urutan prioritas yang jelas dan tegas, misalnya dengan mendahulukan pencapaian sasaran laju inflasi yang rendah daripada pertumbuhan ekonomi yang tinggi. Banyak negara telah menggunakan sasaran tunggal dalam kebijakan moneternya seperti Australia, Selandia Baru, Kanada, dan sebagian besar negara-negara di Eropa. Stanley Fischer (1994), Deputy Managing Director IMF, pernah menyatakan bahwa pengendalian inflasi perlu menjadi sasaran utama kebijakan moneter bank sentral mana pun di dunia. Hal ini didasarkan pada pertimbangan bahwa dalam jangka panjang kebijakan moneter hanya dapat mempengaruhi laju inflasi sedangkan pertumbuhan ekonomi cenderung mengikuti pertumbuhan naturalnya (Guitan, 1994a). Selain itu, pencapaian sasaran tunggal tidak saja dapat menghilangkan trade-off antara sasaran-sasaran yang hendak dicapai tapi juga dapat meningkatkan accountability dan credibility bank sentral. ${ }^{13}$

\section{Mekanisme Penggunaan Suku Bunga sebagai Sasaran Operasional}

Dengan mengadopsi mekanisme transmisi kebijakan moneter di Australia dan Selandia Baru yang disesuaikan dengan instrumen-instrumen pasar keuangan yang tersedia di Indonesia, berikut ini adalah gambaran mekanisme pengendalian moneter melalui suku bunga sebagai sasaran operasional yang mungkin dapat diterapkan di Indonesia.

Dari skema tersebut terlihat bahwa untuk mencapai sasaran akhir berupa pengendalian laju inflasi, Bank Indonesia menggunakan suku bunga jangka pendek, yaitu suku bunga PUAB, sebagai sasaran operasional. Untuk mengendalikan suku bunga PUAB, instrumen utama yang dapat digunakan adalah operasi pasar terbuka (OPT) melalui kegiatan jual/beli SBI/SBPU. Perubahan suku bunga SBI/SBPU akan ditransmisikan ke suku bunga PUAB untuk selanjutnya diteruskan ke suku bunga deposito dan nilai tukar.

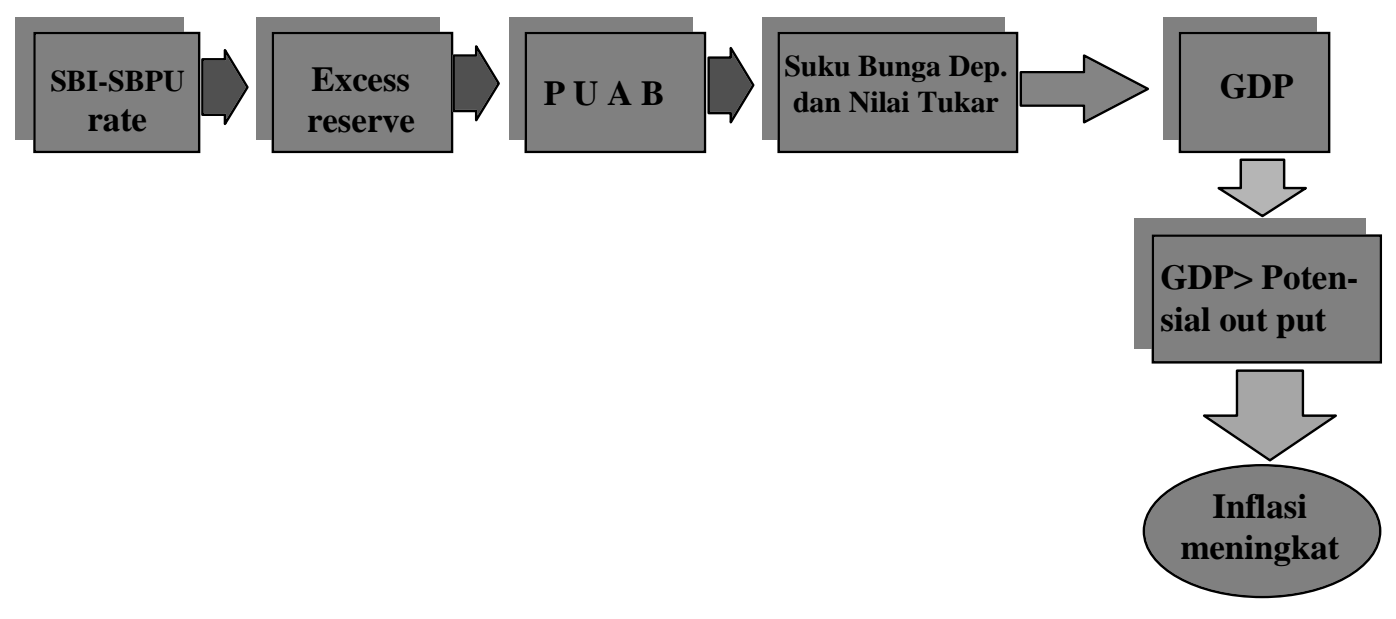

13 Warjiyo, Perry, Manajemen Moneter Dalam Sistim Nilai Tukar Fleksibel:Suatu pemikiran untuk penerapannya di Indonesia, SESPIBI, Nov. 1997 
Nilai tukar rupiah akan dipengaruhi oleh suku bunga PUAB dengan asumsi Indonesia mempertahankan sistem nilai tukar mengambang. Kedua variabel tersebut selanjutnya akan ditransmisikan ke sektor riil melalui pengaruhnya terhadap tingkat output nasional. Perbedaan antara output aktual dengan output potensial akan mempengaruhi laju inflasi.

\section{Operasi Pasar Terbuka (OPT) sebagai Instrumen Utama Pengendalian Moneter}

Untuk mencapai sasaran-sasaran moneter, sejak tahun 1984 Bank Indonesia menggunakan empat instrumen pokok, yaitu penentuan rasio cadangan wajib bank terhadap dana pihak ketiga (reserve requirement), operasi pasar terbuka (OPT), fasilitas diskonto, dan himbauan (moral suasion). Dari keempat kebijakan tersebut yang paling fleksibel untuk digunakan pada situasi normal adalah OPT. Pada saat ini instrumen OPT yang dipakai oleh Bank Indonesia adalah Sertifikat Bank Indonesia (SBI) dan Surat Berharga Pasar Uang (SBPU).

Dalam pengendalian moneter yang menggunakan suku bunga sebagai sasaran, OPT akan menjadi instrumen andalan. Akan tetapi "jiwa" dari penggunaan SBI dan SBPU berbeda dari pengendalian secara kuantitas. Transaksi jual beli SBI dan SBPU harus lebih diarahkan untuk mempengaruhi suku bunga di pasar uang daripada untuk mencapai sasaran besaran-besaran moneter tertentu.

Esensi penerapan sasaran suku bunga dalam konteks mekanisme pasar adalah bank sentral mengendalikan 'harga' (suku bunga) dari dana kliring antarbank. Persyaratan bekerjanya sistem tersebut adalah bank-bank memiliki permintaan akan dana kliring antarbank yang stabil dan bank sentral mampu mengendalikan suplai dana kliring antarbank tersebut. (Lihat Grenville \& Stebbing, p.9)

Elemen pertama sistem pengendalian moneter atas dasar mekanisme pasar adalah permintaan akan dana kliring antarbank:

- Permintaan akan dana kliring antarbank akan selalu ada sepanjang bank sentral mewajibkan bank-bank komersial untuk menyelesaikan hutang antarmereka melalui rekening mereka di bank sentral.

- Hutang antarbank terutama terjadi karena partisipasi bank-bank di dalam sistem pembayaran. Oleh karena itu, kinerja sistem pembayaran menentukan keberadaan dan perkembangan pasar uang.

- Karena bank sentral melaksanakan OPT melalui pasar uang maka efektivitas OPT tergantung pada kinerja sistem pembayaran.

- Permintaan akan dana kliring antarbank (demand for excess reserves) tergantung pada pola transaksi bank-bank, bukan pada ukuran neraca bank-bank. Bank-bank yang lebih banyak melayani rumah tangga-rumah tangga memiliki kebutuhan akan dana kliring antarbank yang lebih kecil daripada bank-bank yang lebih banyak melayani perusahaanperusahaan.

Elemen kedua adalah kemampuan bank sentral untuk mengendalikan suplai dana kliring antarbank. Pengalaman di berbagai negara menunjukkan bahwa terdapat dua hal yang harus dilakukan agar bank sentral mampu mengendalikan neracanya secara efektif: 
- Anggaran pemerintah harus "fully funded" dalam arti setiap kekurangan dana anggaran dibiayai melalui penjualan surat berharga pemerintah kepada sektor swasta. Setiap kenaikan uang primer yang berasal dari pengeluaran bersih bersih pemerintah dan surat berharga pemerintah yang jatuh tempo harus diserap kembali dengan menerbitkan surat berharga baru. Inti dari persyaratan ini adalah bahwa adanya pemisahan antara manajemen moneter (pengendalian dana di pasar keuangan) dan manajemen hutang (pengendalian sumber pembiayaan anggaran pemerintah). Selama ini saldo rekening pemerintah baik di BI maupun di bank-bank selalu positif. Agar saldo tersebut dapat dikendalikan sekaligus menambah instrumen di pasar uang, dapat dilakukan sekuritisasi saldo positif rekening pemerintah dan menggunakannya sebagai instrumen OPT.

- Nilai tukar harus ditentukan oleh pasar sehingga bank sentral tidak lagi harus menyeimbangkan pasar valas melalui jual/beli valas. Secara teoritis, nilai tukar yang mengambang bukan prasyarat utama dalam mengisolasi neraca bank sentral dari faktorfaktor eksternal karena hal tersebut dapat dicapai apabila otoritas moneter mampu menyesuaikan nilai tukar sehingga selalu terjadi keseimbangan di pasar valas atau apabila pemerintah mampu mensterilisasi dampak arus keluar masuk dana dari luar negeri. Namun, pengalaman di banyak negara menunjukkan bahwa kedua hal tersebut sulit dicapai.

Satu prasyarat bagi berjalannya sistem pasar adalah adanya sistem pengawasan kehati-hatian yang baik. Meskipun pasar telah dideregulasi, "nules of the game" tetap diperlukan agar pasar bekerja secara teratur.

Perlu diingat bahwa adanya segmentasi di pasar uang antarbank membuat suku bunga PUAB tidak sepenuhnya mencerminkan kekuatan permintaan dan penawaran di pasar. Akan tetapi terus berlanjutnya reformasi keuangan dan perbankan diharapkan akan mengurangi segmentasi pasar tersebut.

\section{Penentuan Suku Bunga dalam OPT}

Apabila suku bunga dijadikan sasaran operasional dalam pengendalian moneter maka suku bunga nominal akan diarahkan sedemikian rupa sehingga dicapai suku bunga netral. Suku bunga netral adalah suatu tingkat suku bunga di mana variabel-variabel utama seperti inflasi dan tingkat produksi berada pada tingkat yang diinginkan. Untuk itu, ada beberapa "simple rule" untuk menentukan suku bunga qperating target: ${ }^{14}$

- nominal income level rule, $i_{t}=\Phi+p_{t-1}+g\left(p_{t-1}-p^{T}{ }_{t-1}\right)$

- nominal income growth rule, $i_{t}=\Phi+p_{t-1}+g\left(D_{p y}-D_{t-1} p^{T}{ }_{t-1}\right)$

- pure price rule, $i_{t}^{i}=\Phi+p_{t-1}+g\left(p_{t-1}-p_{t-1}^{T}\right)$

- Taylor rule, $\left.i_{t}=\Phi+p_{t-1}+g_{1} p_{t-1}-p^{T}\right)+g_{2}\left(y_{t-1}-\Omega_{t-1}\right)$

- Inflation-only rule, $\left.i_{t}=\Phi+p_{t-1}+g_{1} p_{t-1}-p^{T}\right)$

- change rule, $\left.i_{t}=i_{t 1}+p_{t-1}+g_{1} p_{t-1}-p^{T}\right)+g_{2}\left(y_{t-1}-\Omega_{t-1}\right)$; dan

- constant real interest rate rule, $i_{t}=c+p_{t-1}$ '

dimana:

$i_{t}=$ nominal interest rate

$\stackrel{t}{\Phi}=$ suku bunga riil netral

14 de Brouwer, Gordon and James O’Regan , Evaluataing Simple Monetaray-Policy Rules for Australia, p 


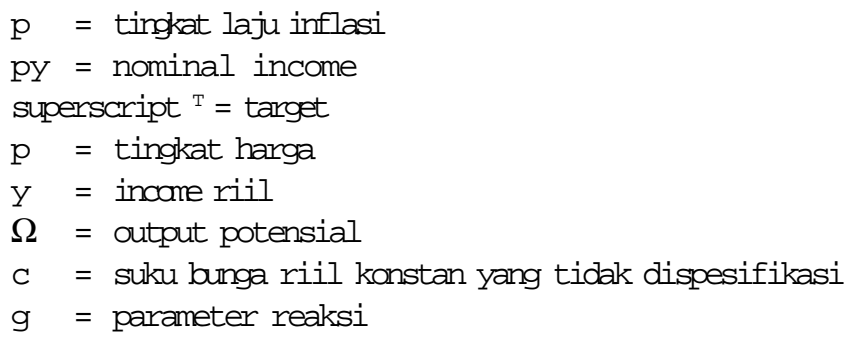

"Simple Rule" merupakan reaction function dimana kebijakan akan berubah sebagai respons terhadap perubahan pada variabel utama. Metode ini tidak seperti "Friedman's constant growth rate" karena penentuan suku bunga di sini lebih diarahkan sebagai pegangan pengambil kebijakan dalam mengimplementasikan suku bunga sebagai sasaran operasional.

Model (nule) mana yang akan dipakai? Untuk itu perlu dikaji nule yang paling efisien dalam pencapaian target. Efisiensi diartikan sebagai makin rendahnya fluktuasi tingkat inflasi dan output gap. Untuk itu, penentuan suku bunga nominal yang baik antara lain memperhatikan sasaran laju inflasi dan juga output gap karena output gap diyakini sebagai penyebab dari munculnya inflasi. Untuk saat ini, Taylor rule dianggap metode yang efisien. ${ }^{15}$ Pada Taylor rule, kebijakan moneter akan mengetat apabila inflasi di atas yang ditargetkan dan tingkat produksi berada di atas tingkat produksi potensial. Dapat dinyatakan bahwa sejak pertengahan 1980-an penggunaan Taylor rule di beberapa negara, antara lain: Amerika Serikat (Taylor, 1993, 1994), Inggris (Stuart, 1996), Jeman dan Jepang (Davies et al., 1996), menunjukkan hasil yang efisien. ${ }^{16}$

Oleh karena Taylor rule merupakan suatu reaction function maka unsur discretionary dalam pengambilan keputusan masih cukup dominan. Sebagai konsekuensinya, efektivitas kebijakan moneter yang menggunakan rule ini sangat tergantung kepada kredibilitas bank sentral.

Satu isu penting dalam menyusun sistem operasional bagi penerapan kebijakan moneter adalah derajat fleksibilitas suku bunga instrumen. Ada dua pilihan yaitu penetapan sasaran suku bunga harian yang dikendalikan secara ketat dan penetapan suku bunga yang masih memberikan sedikit fleksibilitas harian.

- Keuntungan penetapan suku bunga harian secara ketat:

-Memberikan sinyal yang jelas kepada pasar mengenai arah kebijakan moneter.

-Meningkatkan akuntabilitas bank sentral di mata masyarakat.

- Keuntungan adanya fleksibilitas suku bunga harian adalah:

-Dapat mendepolitisasi proses penentuan suku bunga dalam arti politikus tidak dapat memaksakan kehendaknya kepada bank sentral untuk mengubah-ubah suku bunga.

15 Penjelasan lebih detail lihat Gordon de Brower and James O’Regan dalam Evaluating Simple Monetary-Policy Rules for Australia dan Laurence Ball dalam Efficient rules for monetary policy.

16 Ball, Laurence, Efficient rules for monetary policy, p.7 
-Mengurangi keharusan untuk menjelaskan setiap perubahan kecil suku bunga yang terjadi di pasar. Kondisi ini terutama membantu mengurangi beban moral yang harus ditanggung bank sentral ketika harus menaikkan suku bunga.

-Memberikan kesempatan kepada pasar untuk memberikan umpan balik atas kondisi likuiditas pasar. Apabila otoritas menetapkan suku bunga secara harian maka otoritas tidak akan mendapatkan umpan balik dari pasar.

\section{Indikator Kondisi Moneter (IKM) Indonesia}

Di dalam kerangka perekonomian Indonesia yang semakin terbuka dan kebijakan nilai tukar yang semakin fleksibel maka keterkaitan antara suku bunga domestik dan nilai tukar menjadi semakin erat. Tekanan-tekanan eksternal maupun internal tidak lagi hanya ditransmisikan melalui suku bunga tapi juga melalui nilai tukar. Oleh karena itu, perlu dikembangkan suatu formula sasaran antara yang mampu menangkap proses interaksi antara kedua variabel tersebut. Satu alternatif formula yang telah digunakan di beberapa negara adalah indikator kondisi moneter (IKM) .

IKM adalah indikator yang memadukan kadar pengaruh moneter yang berasal dari suku bunga dan nilai tukar terhadap permintaan agregat. Rasio IKM menunjukkan perbandingan kekuatan antara suku bunga dan nilai tukar dalam mempengaruhi permintaan agregat. Di Selandia Baru, rasio IKM adalah 1/2 yang menunjukkan bahwa pengaruh 1\% kenaikan suku bunga sama dengan pengaruh 2\% apresiasi nilai tukar terhadap permintaan agregat (Huxford dan Reddell, 1996). Dengan kata lain, agar permintaan agregat tidak mengalami perubahan maka kenaikan suku bunga sebesar 1\% harus diimbangi dengan depresiasi nilai tukar sebesar $2 \%{ }^{17}$ Di sini terlihat bahwa di Selandia Baru peranan suku bunga lebih besar dibandingkan peranan nilai tukar dalam mempengaruhi permintaan agregat.

IKM Indonesia dapat diperoleh melalui penaksiran yang didasarkan pada model permintaan agregat berikut:

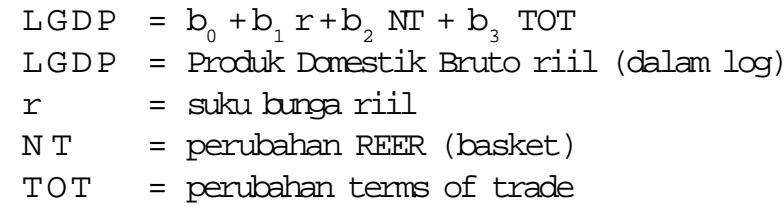

Atas dasar model tersebut dengan menggunakan data sampel 1989.1 s.d 1997.1 diperoleh rasio antara kofisien suku bunga deposito satu bulan riil dengan koefisien nilai tukar sebesar 3,75 (dan sebesar 4,13 jika menggunakan rasio antara deposito tiga bulan dan nilai tukar). Dengan rasio IKM sebesar 3,75, agar permintaan agregat tidak mengalami perubahan maka setiap kenaikan suku bunga sebesar 1\% perlu diimbangi dengan apresiasi nilai tukar sebesar 0,27\%. Hal ini menunjukkan bahwa peranan nilai tukar lebih penting daripada suku bunga dalam mempengaruhi permintaan agregat.

17 Warjiyo, Perry, Manajemen Moneter Dalam Sistim Nilai Tukar Fleksibel: Suatu Pemikiran Untuk Penerapannya di Indonesia, p. 14 
Apabila sampel dibatasi sampai dengan tahun 1995, diperoleh rasio IKM sebesar 1,34 jika menggunakan suku bunga deposito satu bulan dan sebesar 1,51 jika menggunakan suku bunga deposito 3 bulan. Berdasarkan hasil pengujian ini tampak ada suatu perubahan dalam pergerakan pengaruh antara suku bunga dan nilai tukar dalam menjelaskan pertumbuhan ekonomi, terutama setelah tahun 1995. Sekalipun demikian, nilai tukar tetap lebih dominan pengaruhnya terhadap permintaan agregat daripada pengaruh suku bunga.

Dari hasil pengujian tersebut dapat disimpulkan bahwa pengendalian moneter dengan menggunakan suku bunga sebagai sasaran operasional sebaiknya tetap memperhatikan gerakan nilai tukar. IKM dapat dijadikan pedoman sasaran antara yang bersifat tidak formal bagi bank sentral dalam pengendalian moneter.

Untuk menghitung indeks IKM nominal dapat dilakukan sebagai berikut ${ }^{18}$ :

$$
\text { IKM nominal } \left.=\left\{\left(r_{t} \Psi_{b}\right)+3.75 *\left[\log I W I_{t}-\log T W I_{b}\right) * 100\right]\right\} * 100+1000
$$

Sejalan dengan hal tersebut, maka dapat pula dihitung IKM riil sebagai berikut:

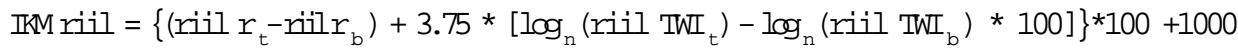

$r_{t} \quad=$ suku bunga nominal periode $t$

$r_{0} \quad=$ suku bunga nominal periode tahun dasar

$\mathrm{TWI} I_{t}=$ trade weighted index nilai tukar nominal periode $t$

TWI $I_{b}=$ trade weighted index nilai tukar nominal periode tahun dasar

Angka 1000 menunjukkan arbitrary fixed base.

Dengan menggunakan arbitrary fixed base sebesar 100 dan angka dasar pada bulan Mei 1995 serta berdasarkan perumusan model di atas maka dapat dilakukan perhitungan Indeks IKM baik nominal maupun indeks riil. Penggunaan IKM nominal akan cenderung bias dalam memperhitungkan dampak inflasi dalam jangka panjang. Akan tetapi dalam jangka pendek IKM nominal dapat digunakan sebagai pendekatan dari IKM riil karena perbedaan antara ekspektasi dan aktual inflasi diasumsikan bersifat gradual. Sedangkan untuk melihat pengaruh IKM terhadap perekonomian riil dalam jangka lebih panjang diperlukan IKM riil. Dengan menggunakan batas bawah dan batas atas masing-masing sebesar 5\% maka perkembangan dari indeks IKM nominal maupun riil dapat digambarkan sebagai berikut :

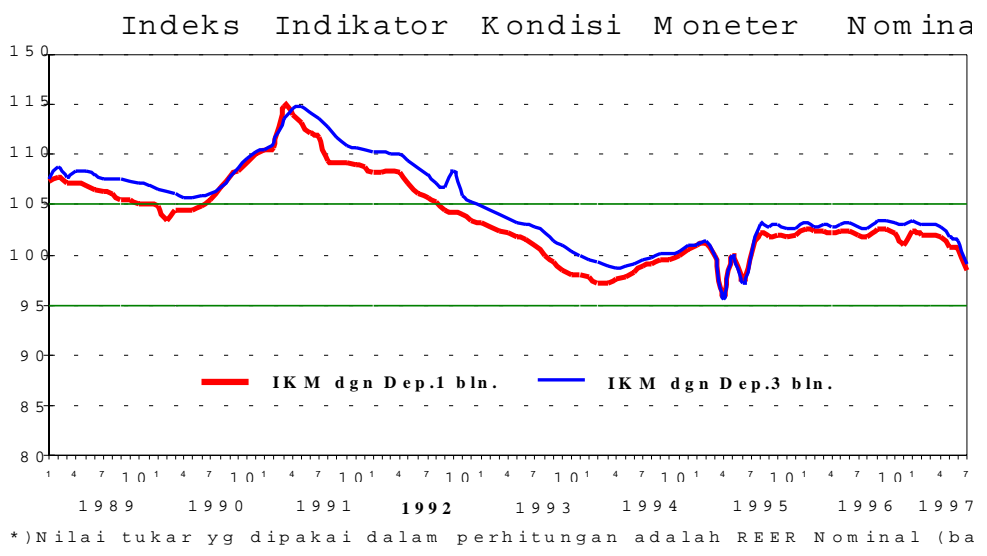

18 RBNZ, How to construct and interpret MCI indices, Monetary Policy Statement, June 1997 


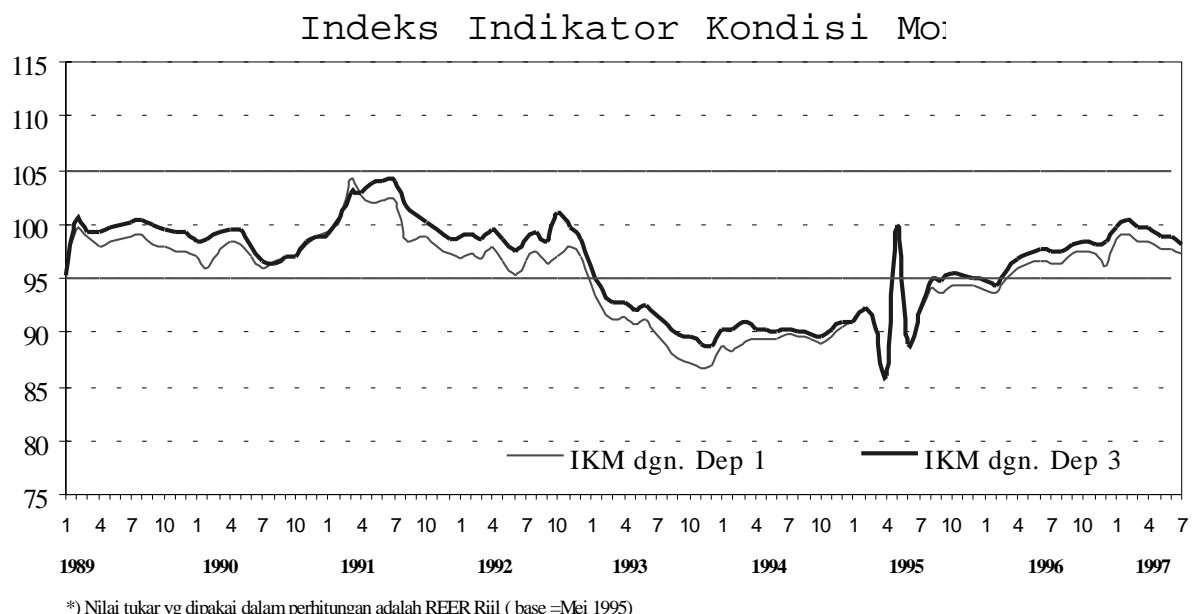

Indeks Indikator Kondisi Moneter N

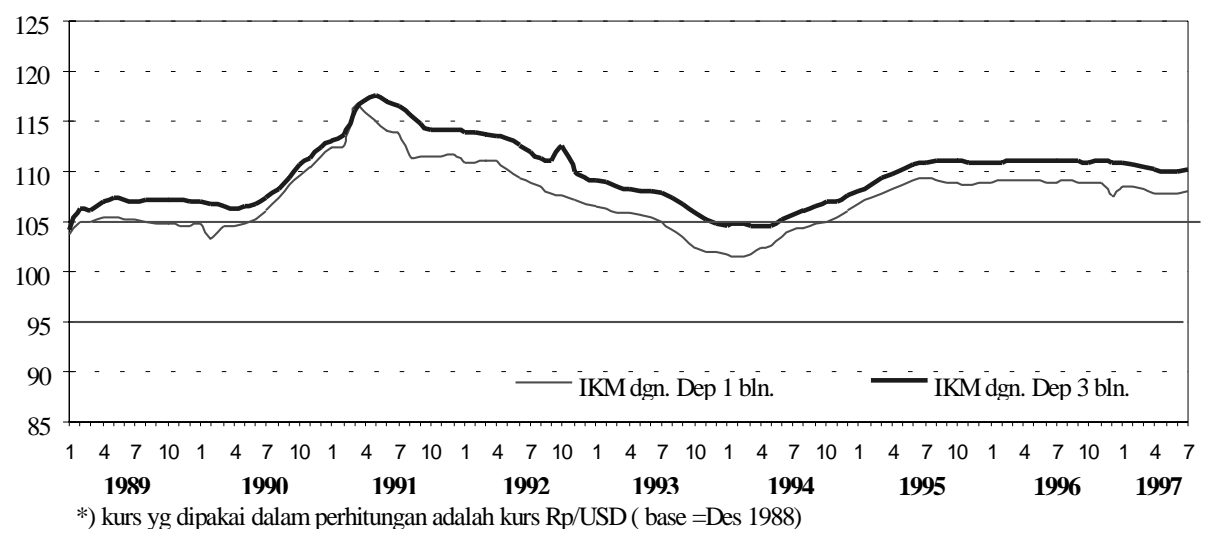

Bila indeks berada di atas batas atas berarti perlu dilakukan kebijakan pelonggaran moneter sedangkan bila indeks berada di posisi di bawah batas bawah maka perlu kebijakan pengetatan moneter.

\section{Kesimpulan dan Saran}

Hasil penjajakan terhadap kemungkinan penerapan sistem pengendalian moneter melalui suku bunga sebagai sasaran operasional menemukan adanya hubungan-hubungan kausalitas yang signifikan antara suku bunga (deposito satu bulan) dan sasaran akhir (laju inflasi) serta antara instrumen kebijakan moneter (suku bunga SBPU) dan suku bunga (deposito satu bulan) .

Agar efektif, pengendalian moneter melalui suku bunga sebagai sasaran operasional hendaknya memperhatikan hal-hal berikut: 
- Sasaran akhir kebijakan moneter hendaknya hanya diprioritaskan kepada sasaran tunggal laju inflasi, khususnya laju inflasi underlying .

- Sistem lelang SBI sebaiknya menggunakan sistem COR yang sejalan dengan "jiwa" penggunaan suku bunga sebagai sasaran operasional.

- Mengingat belum adanya acuan suku bunga jangka panjang di Indonesia, perlu diperkenalkan instrumen semacam obligasi pemerintah (treasury bill).

Untuk semakin memperkuat landasan bagi penerapan sistem pengendalian moneter menggunakan suku bunga sebagai sasaran operasional, perlu dilakukan penelitianpenelitian lanjutan mengenai:

- Estimasi permintaan agregat dan penawaran agregat serta output gap yang lebih akurat.

- Penghitungan tingkat suku bunga netral untuk Indonesia.

- Pengujian model IKM yang lebih akurat dengan memperhitungkan sistem nilai tukar mengambang yang kini diterapkan di Indonesia.

- Pengujian ketepatan policy mix dan policy assigmment di antara tiga kebijakan ekonomi makro, yaitu kebijakan moneter, fiskal, dan nilai tukar. 


\section{Daftar Pustaka}

Boediono, Mekanisme Transmisi Kebijakan Moneter, Disampaikan pada Kuliah Khusus SESPIBI, 24 September 1996.

Debelle, Guy, dan Glenns Stevens, Mbnetary Policy Goals for Inflation in Australia, Reserve Bank of Australia Discussion Paper, 9503, 1995.

De Brouwer, Gordon, dan J. Oregan, Evaluating Simple Monetary Policy Rules for Australia, 1997.

De Brouwer, Gordon, Irene Ng, dan Robert Subbaraman, The Demand for Money in Australia: New Test on an Old Topic, Reserve Bank of Australia Reserach Discussion Paper, 9314, 1993.

Eckhold Kelly, Monetary Policy Theory and Practice in New Zealand, RBNZ, 1997.

Fahrer, Jerome, dan Lynne-Elle Shori, An Empericel Mbolel of Australian Interest Rate, Exchange Rates and Monetary Policy, Reserve Bank of Australia Research Discussion Paper, 9009, 1990.

Grenville, S.A, dan P.W. Stebbing, Monetary Management: the Australian Experience, International Coference on Monetary Management, 1994.

Horton, Tracey, dan Jenny Wilkinson, An Analysis of the Determinants of Imports, Peserve Bank of Australia Research Discussion Paper -8910, 1989.

MacFarlane, Ian, dan Warren Tease, Capital flows and Exchange Rate Detemination, Reserve Bank of Australia Research Discussion Paper, 8908, 1989.

Morris, Dirk, Monetary Transmission in a Dergulated Financial System, Reserve Bank of Australia Research Discussion Paper, 8811, 1988.

RBNZ, Measures of Underlying Inflation in New Zealand, 1981-95, 1995. , Summary Indicators of Monetary Condition, 1997.

Roger, Scott, An Illustarated Guide to the Role of Underlying Inflation in Mbnetary Policy, Reserve Bank of New Zealand Bulletin, Vo.57(3), h.234-242, 1994.

Sarwono, Hartadi A., Mencari Paradigma Baru Mekanisme Transmisi Sistem Pengendalian Moneter: Suatu Studi Kemungkinan Penerapannya, Makalah SESPIBI XXI, 1996.

Stevens, Glenn, dan Jenny Wilkinson, The Monetary Policy Transmission Process in Australia: What Do We know ?

Siklos, Pierre L., Searching for Improved Monetary Indicator for New Zealand, RBNZ Discussion Paper Series - G96/1, 1996.

The Demand for Mbney in New Zealand in Era of Institutional Change: Evidence from the 1981 - 1994 Period, RBNZ Discussion Paper Series - G95/3, 1995.

Warjiyo, Perry, Manajemen Moneter Dalam Sistim Nilai Tukar Fleksibel: Suatu Pemikiran Untuk Penerapannya di Indonesia, SESPIBI XXII, November, 1997 
Lampiran

\section{Kerangka Kerja Tinbergen}

Misalkan, hubungan antara kebijakan fiskal (G) dan kebijakan moneter (M) dalam mempengaruhi pencapaian sasaran pengendalian tingkat produksi (Q) dan tingkat hargaharga (P) dapat dipresentasikan ke dalam sistem persamaan linear berikut:

$$
\begin{aligned}
& \mathrm{Q}=\mathrm{a}_{1} \mathrm{G}+\mathrm{a}_{2} \mathrm{M} \\
& \mathrm{P}=\mathrm{b}_{1} \mathrm{G}+\mathrm{b}_{2} \mathrm{M}
\end{aligned}
$$

Koefisien-koefisien $\mathrm{a}_{1}, \mathrm{a}_{2}, \mathrm{~b}_{1}$, dan $\mathrm{b}_{2}$ mengukur pengaruh kuantitatif kebijakan fiskal dan moneter terhadap produksi dan harga. Sistem persamaan tersebut dapat diubah ke dalam notasi matriks berikut:

$$
\begin{aligned}
& \lceil\mathrm{Q}\rceil=\left\lceil\mathrm{a}_{1} \mathrm{a}_{2}\right\rceil\lceil\mathrm{G}\rceil \\
& \lfloor\mathrm{P}\rfloor=\left\lfloor\mathrm{b}_{1} \mathrm{~b}_{2}\right\rfloor\lfloor\mathrm{M}\rfloor
\end{aligned}
$$

Dengan menggunakan Metoda Kramer dapat dibuktikan bahwa untuk mencapai $Q=Q^{*}$ dan $\mathrm{P}=\mathrm{P}^{\star}$ maka kombinasi kebijakan fiskal dan moneter yang harus diambil adalah:

$$
G=\frac{\left(b_{2} Q^{\star}-a_{2} P^{\star}\right)}{\left(a_{1} b_{2}-b_{1} a_{2}\right)} \quad M=\frac{\left(b_{2} P^{\star}-a_{2} Q^{\star}\right)}{\left(a_{1} b_{2}-b_{1} a_{2}\right)}
$$

Penyebut dari kedua persamaan di atas tidak lain adalah kœfisien deteminasi matriks di atas. Apabila koefisien deteminasi suatu matriks sama dengan nol maka solusi kedua persamaan tidak dapat ditemukan kecuali salah satu sasaran dikorbankan. Koefisien determinasi yang sama dengan nol juga dapat diartikan bahwa terdapat hubungan kausalitas antara masing-masing sasaran. Hal ini dapat dibuktikan sebagai berikut:

$$
\begin{aligned}
& \mathrm{Q}=\mathrm{a}_{1} \mathrm{G}+\mathrm{a}_{2} \mathrm{M} \\
& \mathrm{P}=\mathrm{g} \mathrm{Q}
\end{aligned}
$$

Persamaan kedua menunjukkan tingkat harga sepenuhnya ditentukan oleh tingkat produksi. Dengan mensubstitusikan persamaan pertama ke dalam persamaan kedua akan diperoleh:

$$
\begin{aligned}
& \mathrm{Q}=\mathrm{a}_{1} \mathrm{G}+\mathrm{a}_{2} \mathrm{M} \\
& \mathrm{P}=\mathrm{g} \mathrm{a}_{1} \mathrm{G}+\mathrm{g} \mathrm{a}_{2} \mathrm{M}
\end{aligned}
$$

Koefisien deteminasi dari sistem persamaan di atas adalah:

$$
g a_{1} a_{2}-g a_{1} a_{2}=0 \text {. }
$$

Jadi, dapat disimpulkan bahwa apabila kebijakan moneter dan fiskal hanya dapat mempengaruhi laju inflasi secara tidak langsung melalui pengaruh kedua kebijakan tersebut terhadap tingkat produksi maka sasaran produksi dan laju inflasi tidak mungkin dapat dicapai secara bersamaan. Kalau pun koefisien determinasi tidak sama dengan nol namun mendekati nol maka pencapaian kedua sasaran secara bersama-sama hanya dapat terjadi apabila masing-masing instrumen kebijakan berada jauh di atas/bawah tingkat nomalnya. 